Prepared in cooperation with the U.S. Environmental Protection Agency

\title{
Geochemistry of Standard Mine Waters, Gunnison County, Colorado, July 2009
}

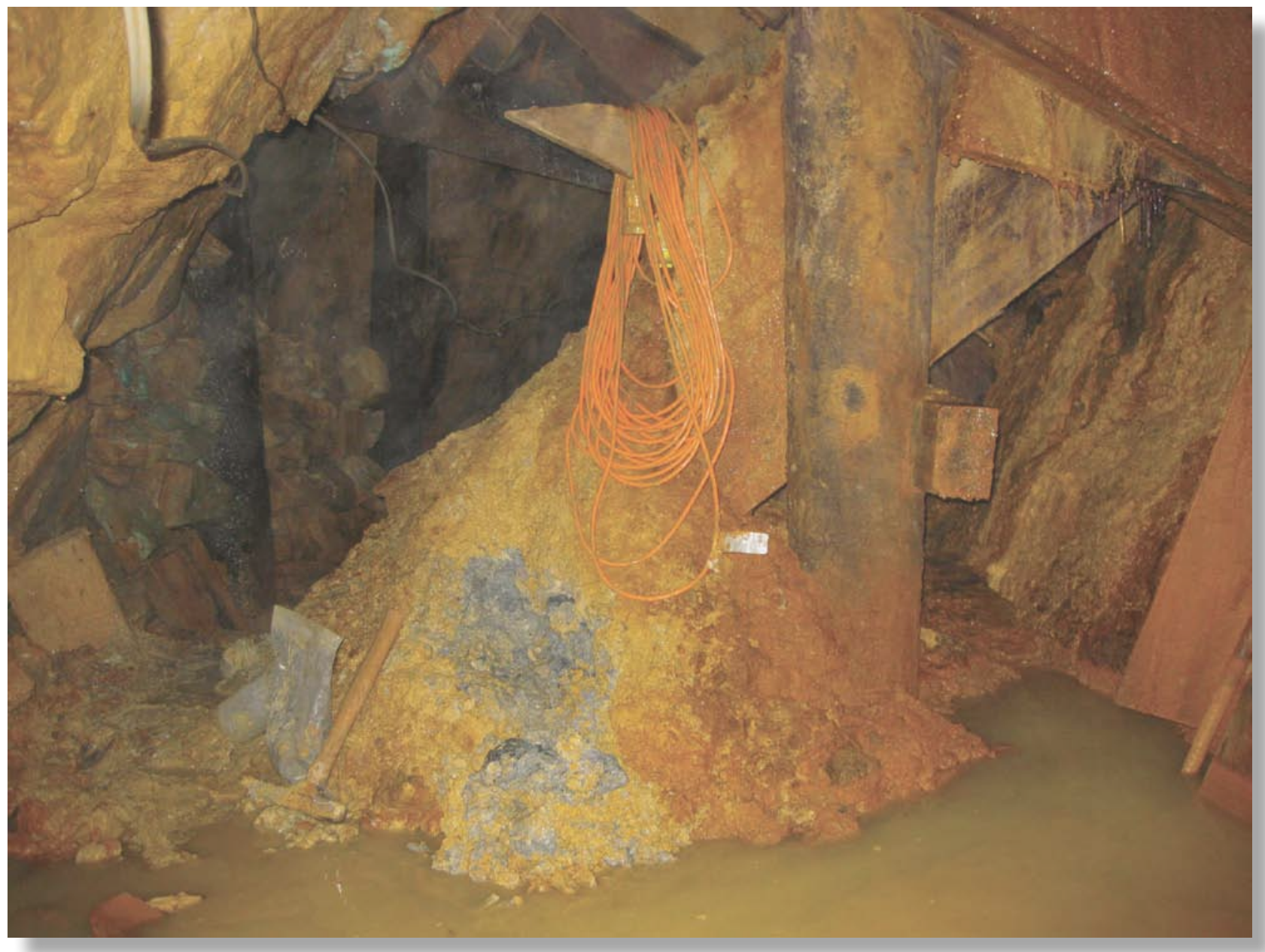

Open-File Report 2009-1292 
Front cover: View of metal-rich mined material below ore chute, Level 3, the Standard Mine near Crested Butte, Colorado, July 2009. 


\section{Geochemistry of Standard Mine Waters, Gunnison County, Colorado, July 2009}

By Philip L. Verplanck, Andrew H. Manning, Jeffrey T. Graves, R. Blaine McCleskey, Todor Todorov, and Paul J. Lamothe

Prepared in cooperation with the U.S. Environmental Protection Agency

Open-File Report 2009-1292 


\title{
U.S. Department of the Interior \\ KEN SALAZAR, Secretary \\ U.S. Geological Survey \\ Marcia K. McNutt, Director
}

\section{U.S. Geological Survey, Reston, Virginia: 2010}

\author{
For more information on the USGS — the Federal source for science about the Earth, its natural and living resources, \\ natural hazards, and the environment, visit http://www.usgs.gov or call 1-888-ASK-USGS \\ For an overview of USGS information products, including maps, imagery, and publications, \\ visit http://www.usgs.gov/pubprod \\ To order this and other USGS information products, visit http://store.usgs.gov
}

\begin{abstract}
Any use of trade, product, or firm names is for descriptive purposes only and does not imply endorsement by the U.S. Government.

Although this report is in the public domain, permission must be secured from the individual copyright owners to reproduce any copyrighted materials contained within this report.
\end{abstract}

Suggested citation:

Verplanck, P.L., Manning, A.H., Graves, J.T., McCleskey, R.B., Todorov, Todor, and Lamothe, P.J., 2010, Geochemistry of Standard Mine waters, Gunnison County, Colorado, July 2009: U.S. Geological Survey Open-File Report 2009-1292, $21 \mathrm{p}$. 


\section{Contents}

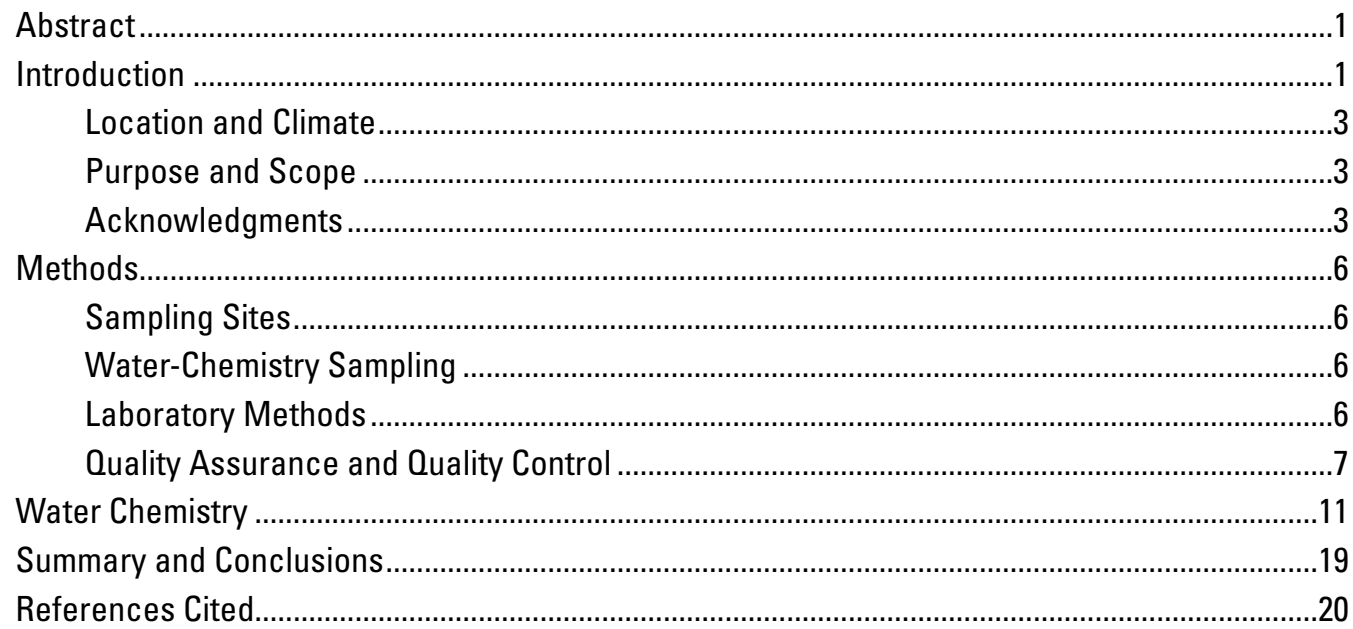

\section{Figures}

1. Map of Colorado with expanded view showing location of the Standard Mine ..............2

2. Cross-sectional view of the Standard Mine workings ...................................................

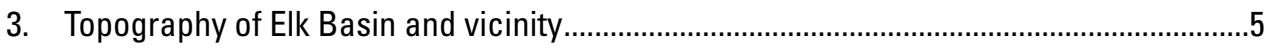

4. Graph showing cumulative monthly precipitation...............................................................

5. Level 2 of the Standard Mine showing sample sites .......................................................

6 Level 3 of the Standard Mine showing sample sites........................................................

7. Graphs showing comparison of analytical results by inductively coupled plasma atomic-emission spectroscopy and inductively coupled plasma-mass spectrometry with $(A)$ barium concentration; $(B)$ manganese concentration; and $(C)$ strontium concentration

8. Graphs showing comparison of 2006 and 2009 chemical results with

$(A) \mathrm{pH} ;(B)$ specific conductance; $(C)$ sulfate concentration; and

(D) zinc concentration

9. Cross-sectional view of the Standard Mine workings with sample $\mathrm{pH}$ and specific conductance (SC)

10. Graphs showing sample site level and concentration of $(A)$ sulfate; $(B)$ calcium; $(C)$ magnesium; $(D)$ manganese; $(E)$ zinc; and $(F)$ cadmium in milligram per liter ...........15

11. Cross-sectional view of the Standard Mine workings with sample sulfate and zinc concentration

12. Graph showing zinc concentration in relation to cadmium concentration ......................18

13. Photograph showing ore chute with pile of mined material below, Standard Mine Level 3

14. Graph showing hydrogen isotopic composition $\left(\delta^{2} \mathrm{H}\right)$ in relation to oxygen isotopic composition $\left(\delta^{18} 0\right)$ of waters and the global meteoric water line 


\section{Tables}

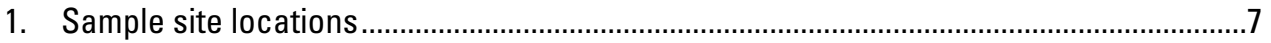

2. Methods of analysis and detection limits ...................................................................... 10

3. Water analyses of study samples ............................................................................... link

4. Inductively coupled plasma-mass spectrometry analyses of study samples.............. link

5. Oxygen-18 and deuterium isotopic content of water samples .........................................13

\section{Conversion Factors}

Inch/Pound to SI

\begin{tabular}{|c|c|c|}
\hline Multiply & By & To obtain \\
\hline \multicolumn{3}{|c|}{ Length } \\
\hline inch (in.) & 25,400 & micrometer $(\mu \mathrm{m})$ \\
\hline foot $(\mathrm{ft})$ & 0.3048 & meter $(\mathrm{m})$ \\
\hline mile (mi) & 1.609 & kilometer $(\mathrm{km})$ \\
\hline \multicolumn{3}{|c|}{ Area } \\
\hline square mile $\left(\mathrm{mi}^{2}\right)$ & 259.0 & hectare (ha) \\
\hline square mile $\left(\mathrm{mi}^{2}\right)$ & 2.590 & square kilometer $\left(\mathrm{km}^{2}\right)$ \\
\hline \multicolumn{3}{|c|}{ Volume } \\
\hline cubic inch $\left(\right.$ in $\left.^{3}\right)$ & 16,390 & microliter $(\mu \mathrm{L})$ \\
\hline \multicolumn{3}{|c|}{ Flow rate } \\
\hline inch per year (in/yr) & 25.4 & millimeter per year (mm/yr) \\
\hline acre-foot per day (acre-ft/d) & 0.01427 & cubic meter per second $\left(\mathrm{m}^{3} / \mathrm{s}\right)$ \\
\hline
\end{tabular}

Temperature in degrees Celsius $\left({ }^{\circ} \mathrm{C}\right)$ may be converted to degrees Fahrenheit $\left({ }^{\circ} \mathrm{F}\right)$ as follows:

$$
{ }^{\circ} \mathrm{F}=\left(1.8 \times{ }^{\circ} \mathrm{C}\right)+32
$$

Vertical coordinate information is referenced to the North American Vertical Datum of 1988 (NAVD 88).

Horizontal coordinate information is referenced to the insert North American Datum of 1983 (NAD 83).

Altitude, as used in this report, refers to distance above the vertical datum.

Specific conductance is given in microsiemens per centimeter at 25 degrees Celsius $(\mu S / \mathrm{cm}$ at $25^{\circ} \mathrm{C}$ ). Concentrations of chemical constituents in water are given either in milligrams per liter (mg/L) or micrograms per microliter ( $\mu \mathrm{g} / \mathrm{L})$. 


\title{
Geochemistry of Standard Mine Waters, Gunnison County, Colorado, July 2009
}

\author{
By Philip L. Verplanck, Andrew H. Manning, Jeffrey T. Graves'', R. Blaine McCleskey, Todor Todorov, \\ and Paul J. Lamothe
}

\section{Abstract}

In many hard-rock-mining districts water flowing from abandoned mine adits is a primary source of metals to receiving streams. Understanding the generation of adit discharge is an important step in developing remediation plans. In 2006, the U.S. Environmental Protection Agency listed the Standard Mine in the Elk Creek drainage basin near Crested Butte, Colorado as a superfund site because drainage from the Standard Mine enters Elk Creek, contributing dissolved and suspended loads of zinc, cadmium, copper, and other metals to the stream. Elk Creek flows into Coal Creek, which is a source of drinking water for the town of Crested Butte. In 2006 and 2007, the U.S. Geological Survey undertook a hydrogeologic investigation of the Standard Mine and vicinity and identified areas of the underground workings for additional work. Mine drainage, underground-water samples, and selected springwater samples were collected in July 2009 for analysis of inorganic solutes as part of a follow-up study.

Water analyses are reported for mine-effluent samples from Levels 1 and 5 of the Standard Mine, underground samples from Levels 2 and 3 of the Standard Mine, two spring samples, and an Elk Creek sample. Reported analyses include field measurements ( $\mathrm{pH}$, specific conductance, water temperature, dissolved oxygen, and redox potential), major constituents and trace elements, and oxygen and hydrogen isotopic determinations. Overall, water samples collected in 2009 at the same sites as were collected in 2006 have similar chemical compositions. Similar to 2006, water in Level 3 did not flow out the portal but was observed to flow into open workings to lower parts of the mine. Many dissolved constituent concentrations, including calcium, magnesium, sulfate, manganese, zinc, and cadmium, in Level 3 waters substantially are lower than in Level 1 effluent. Concentrations of these dissolved constituents in water samples collected from Level 2 approach or exceed concentrations of Level 1 effluent suggesting that water-rock interaction between Levels 3 and 1 can account for the elevated concentration of metals and other constituents in
Level 1 portal effluent. Ore minerals (sphalerite, argentiferous galena, and chalcopyrite) are the likely sources of zinc, cadmium, lead, and copper and are present within the mine in unmined portions of the vein system, within plugged ore chutes, and in muck piles.

\section{Introduction}

In many hard-rock-mining districts water flowing from abandoned mine portals is a primary source of metals and acidity to receiving streams. In mountain settings, many mining operations tunneled at the base of the ore deposit to allow water to drain from the mine workings and to use gravity to move ore and waste rock from the mine. Tunnel-discharge waters represent a complex mixture of groundwater from various sections of the underground workings and from the surrounding groundwater-flow system. Understanding the generation of mine-portal discharge is an important step in developing remediation plans.

In 2006, the U.S. Environmental Protection Agency (USEPA) listed the Standard Mine in the Elk Creek drainage basin near Crested Butte, Colorado (fig. 1) as a Superfund Site because drainage from the Standard Mine enters Elk Creek, contributing dissolved and suspended loads of zinc, cadmium, copper, and other metals to the stream. Elk Creek flows into Coal Creek, which is a source of drinking water for the town of Crested Butte. In 2006 and 2007, the U.S. Geological Survey (USGS) was asked to characterize the ground-water flow system in the vicinity of the Standard Mine in order to assist the USEPA in evaluating remedial options for the mine (Verplanck and others, 2007; Manning and others, 2008a; Manning and others, 2008b).

The Standard Mine is an abandoned, underground, hardrock mine within the Ruby mining district that was mined intermittently from 1880 through the 1960s (Wood and Oerter, 2007). Metals mined at the deposit included silver, lead, zinc, and copper. The primary mineral deposit exploited was a

${ }^{1}$ Colorado Division of Reclamation Mining and Safety. 


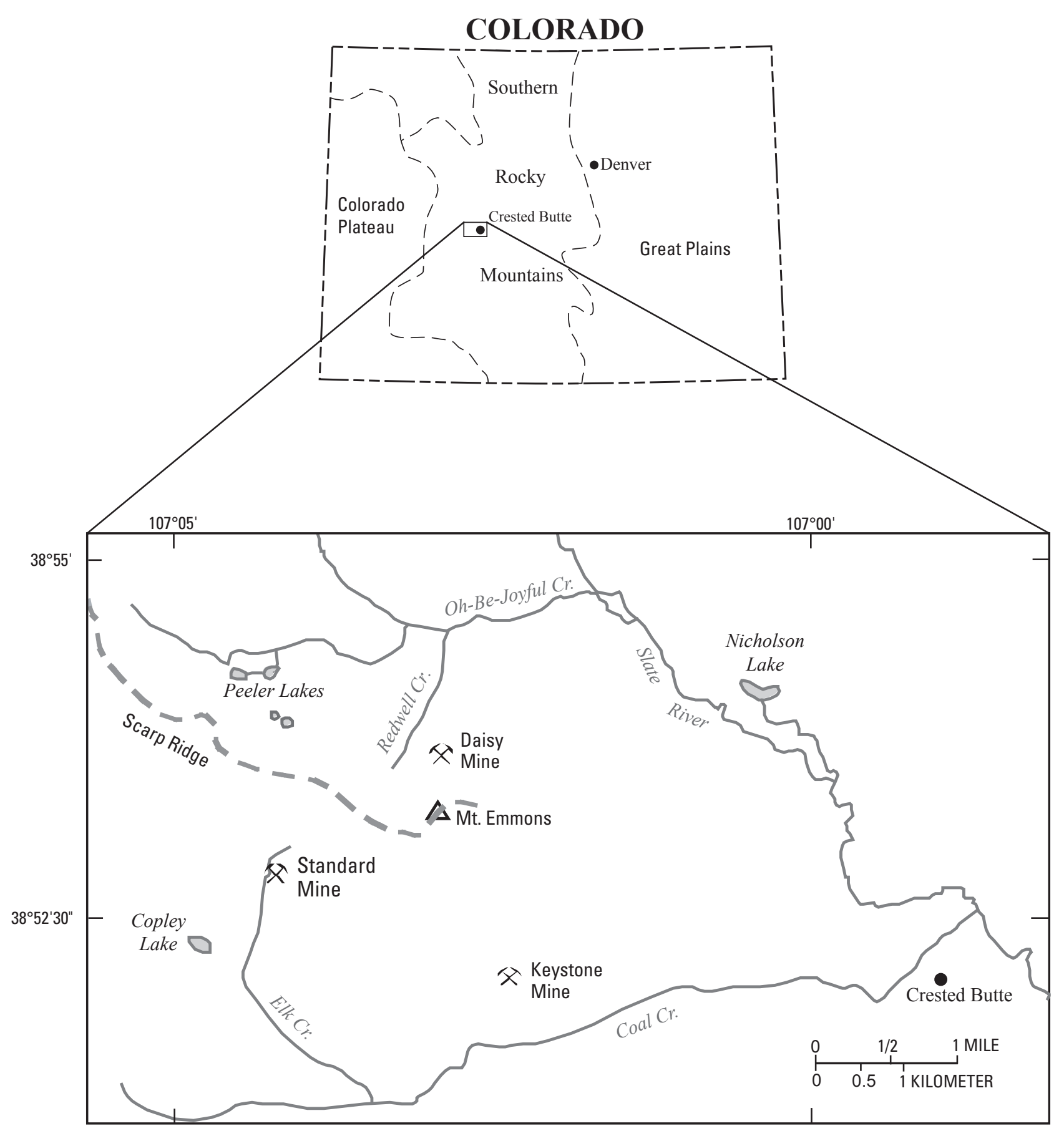

Base from U.S. Geological Survey Paonia, Colorado (1983) and Gunnison, Colorado (1984) topographic maps, 1:100,000

Figure 1. Colorado with expanded view showing location of the Standard Mine. 
polymetallic vein system associated with the Standard fault that contained sphalerite, pyrite, argentiferous galena, and chalcopyrite. Sharp (1978) concluded that the poly-metallic vein mineralization in Elk Basin (including the Standard fault vein) appear genetically and spatially related to an underlying Tertiary rhyolite porphyry stock, exposed to the northeast in Redwell basin.

The workings of the Standard Mine are described in detail in two underground assessment reports (Colorado Division of Reclamation, Mining, and Safety, 2007; Graves, 2009). Briefly, the mine consists of four adits and several stopes and shafts that generally follow the Standard fault vein. The adits are designated Levels 1, 2, 3, and 5, in sequence from lowermost to uppermost. Levels 1, 2, and 3 are connected by stopes or raises (fig. 2). The Level 2 portal is collapsed, such that Level 2 only can be accessed by descending from Level 3 through vertical workings. The Level 5 tunnel is not connected to the other levels. The Level 1 and Level 5 portals are the only portals that consistently drain water. Level 1 discharges considerably more water than the other levels and thus is the largest potential source of metals in Elk Creek associated with the Standard Mine. In August 2006 and July 2009, water was observed inside Level 3 that was draining to lower levels through raises.

One component of the previous study was the collection of water-quality samples from mined areas within the Elk Creek drainage. An important observation was that concentrations of many constituents, including calcium, sulfate, magnesium, sodium, potassium, manganese, zinc, cadmium, and strontium, in Level 1 discharge were greater than in any of the Level 3 underground samples. Concentrations of many metals were elevated in Level 3 samples compared to samples of springs emanating from the local bedrock suggesting that interaction with sulfide-rich material within the Standard fault vein and mine workings is a primary control on solute chemistry. A likely source zone for the elevated metals observed in Level 1 discharge water is located between Levels 1 and 3, because it is the portion of the mine with the most extensive stoping, and presumably, a high degree of mineralization. However, because of safety concerns, samples from Level 2 were not collected in 2006.

This investigation was undertaken as a follow-up study to address some of the unresolved issues from the 2006 work. An important objective of this study was to evaluate the hypothesis that a substantial component of the metal load in Level 1 discharge originates between Levels 1 and 3. In addition to this study, an investigation to characterize the geologic structures and host-rock properties in Elk Basin (Caine and others, in press) and an investigation was done to characterize the near subsurface geophysical properties of the Standard Mine (Minsley and others, in press).

\section{Location and Climate}

The Standard Mine is located within the upper Elk Creek drainage basin (Elk Basin), a roughly 1-square mile alpine watershed located approximately 4 miles west-northwest of Crested Butte in west-central Colorado (fig. 1). Land-surface elevations in Elk Basin range from 10,800 to 12,200 feet (ft), and topographic gradients generally range from 0.2 to 0.6 , typical of rugged mountain settings (fig. 3). Vegetation is subalpine to alpine, dominantly mixed spruce and fir forest or tundra. The closest meteorological stations are in Crested Butte at an elevation of $8,860 \mathrm{ft}$ (http://www.wrcc.dri.edu) and at Crested Butte Ski Area about $6 \mathrm{mi}$ to the east at an elevation of 10,160 ft (http://www.wcc.nrcs.usda.gov/snotel). Data from these stations indicate that Elk Basin has a mean annual air temperature of about $1{ }^{\circ} \mathrm{C}$ and mean annual precipitation of about 31 inches per year, with about 65 percent of precipitation typically falling as snow. Snow cover generally persists from November through May. Elk Basin is drained by Elk Creek, a perennial stream and a tributary to Coal Creek.

Although the 2006 USGS investigation went through June 2007, most of the samples, including all the Standard Mine underground samples, were collected August 15-17, 2006. Samples for this study were collected July 20-22, 2009. Overall the precipitation recorded at Crested Butte SNOTEL site (http://www.wcc.nrcs.usda.gov/snotel) for water years 2006 and 2009 was quite similar to the 1971 to 2000 average (fig. 4).

\section{Purpose and Scope}

The purpose of this report is to present water-quality data from the USGS July 2009, ground-water investigation at the Standard Mine. The data set includes samples collected from the Level 1 and Level 5 portals, 5 samples collected underground in Level 3, and 2 springs, all collected at previously sampled sites (July 2006) to evaluate temporal variations. In addition 6 water samples from Level 2 were collected to constrain the source of metals in the Level 1 portal discharge. Data presented in this report include field measurements of $\mathrm{pH}$, specific conductance, dissolved oxygen, redox potential (Eh), and water temperature, as well as laboratory determinations of major constituents, selected trace element concentrations, and oxygen and hydrogen isotopic determinations.

\section{Acknowledgments}

This work was done in cooperation with the USEPA. We greatly appreciate the efforts of Steve Renner, Al Amundson, Craig Bissonnette, Erica Crosby and Tara Tafi of the Colorado 


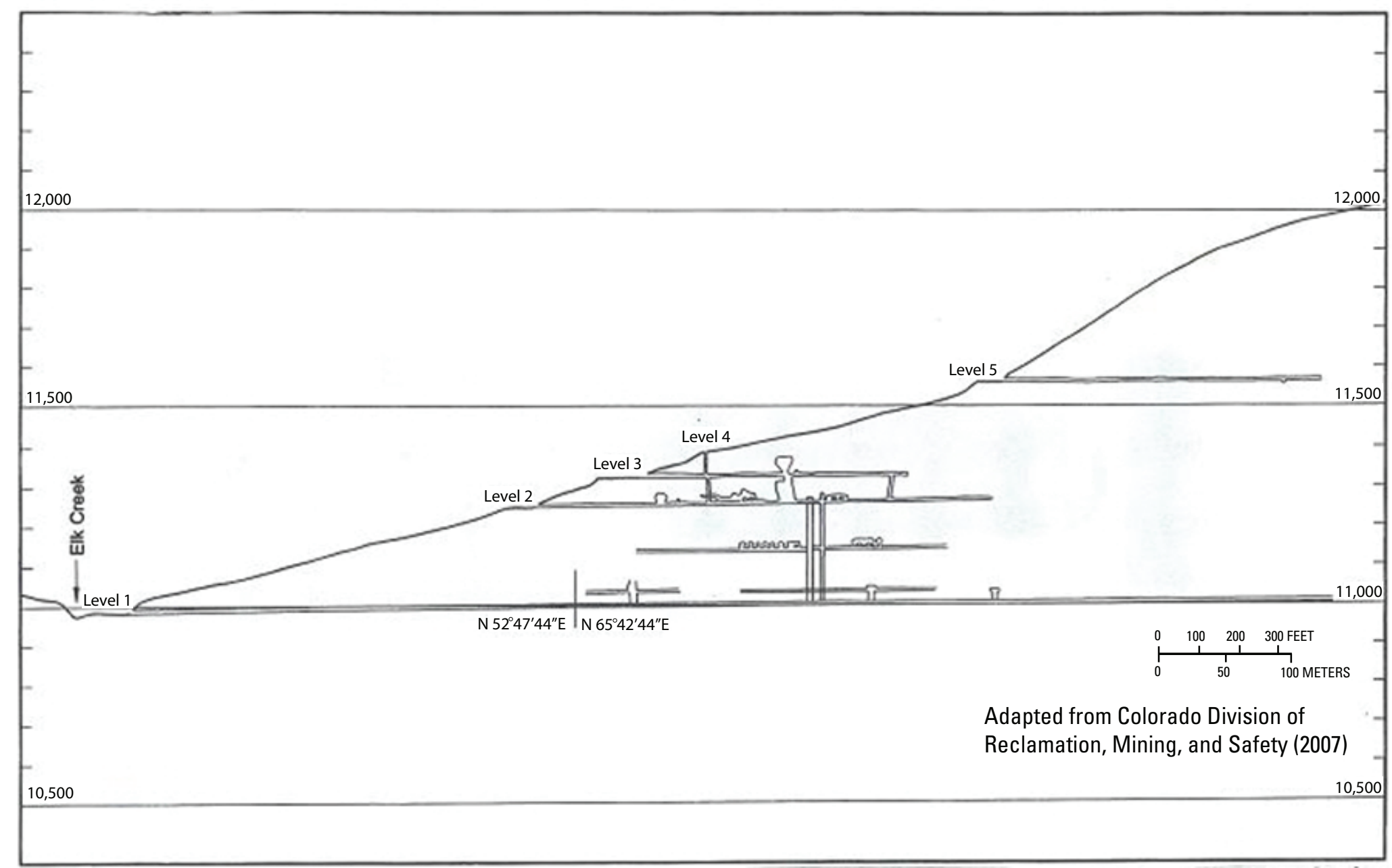

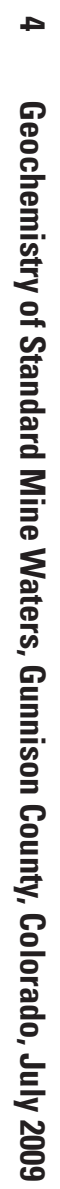

Figure 2. Cross-sectional view of the Standard Mine workings (sketch from U.S. Environmental Protection Agency). 


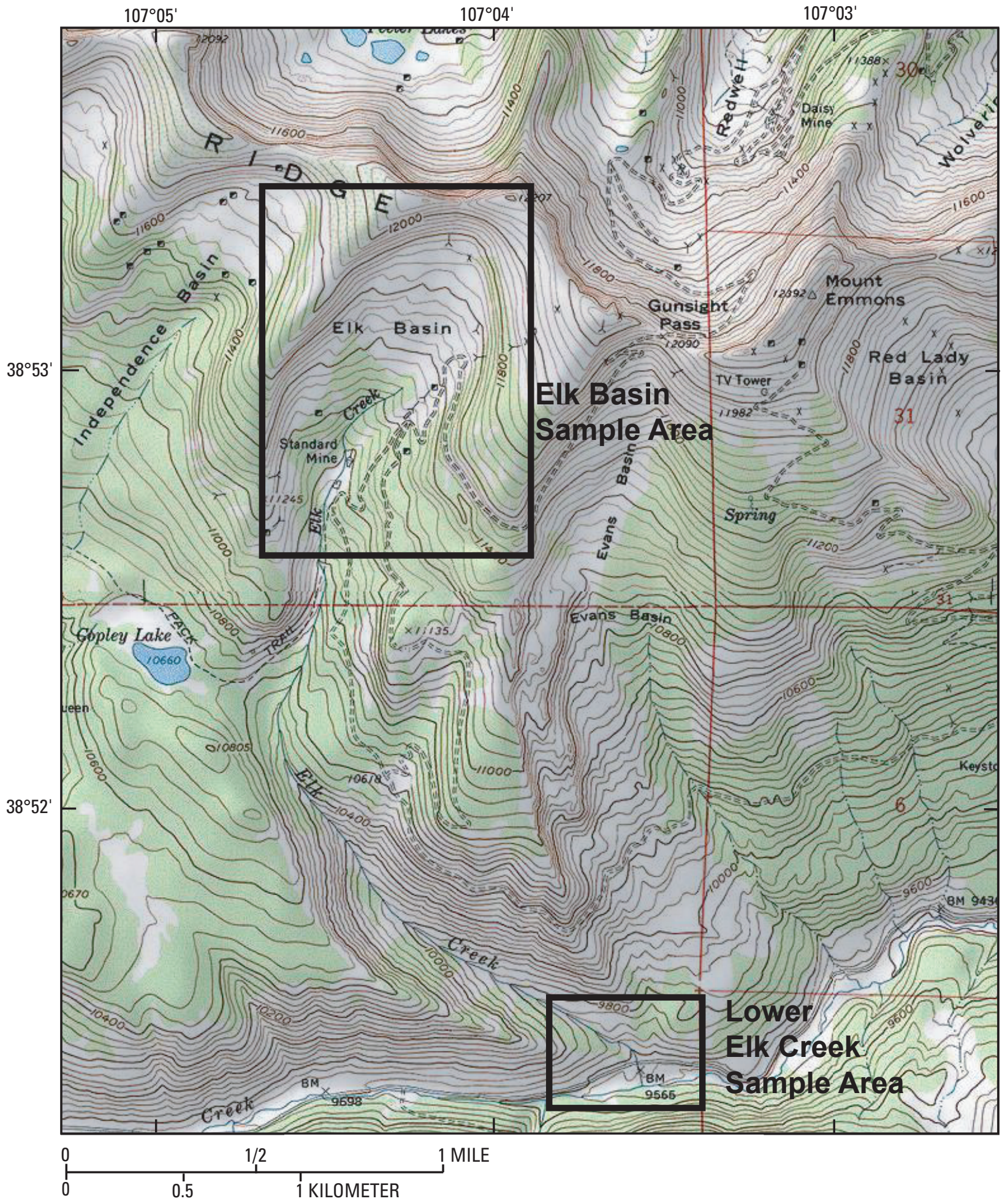

Base from U.S. Geological Survey Oh-Be-Joyful and Mt. Axtel quadrangles, 1:24,000 (1961)

Figure 3. Topography of Elk Basin and vicinity. 


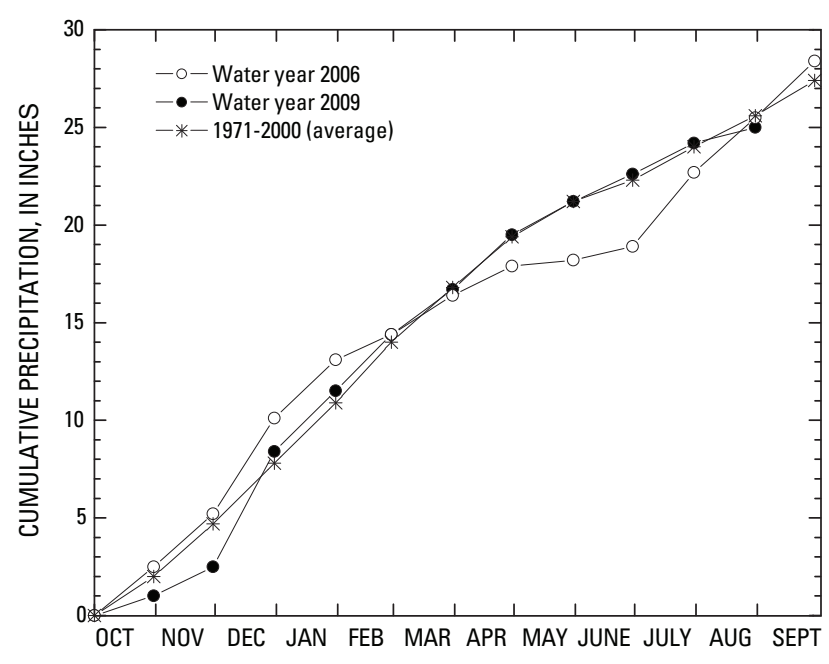

Figure 4. Diagram showing cumulative monthly precipitation.

Division of Reclamation, Mining, and Safety (CDRMS) for escorting us into the mine and accessing Level 2. We thank Thomas Chapin and JoAnn M. Holloway of the USGS for their constructive comments during the preparation and review of this report.

\section{Methods}

\section{Sampling Sites}

Table 1 and figures 5 and 6 provide the locations of samples. Samples were collected of Level 1 and Level 5 portal discharge (EC-MSTDL1 and EC-M11600). Sampling sites along Level 3 were at the same sample locations as July 2006 (fig. 5). Six samples were collected from Level 2 (fig. 6). Because of limited access to Level 2, grab samples were collected by CDRMS personnel. Three surface-water samples were collected from sites sampled in 2006 including: one sample from a seep emanating from waste-rock material below the Level 5 adit (EC-S1), one sample from a spring near Level 1 (EC-S8), and one from Elk Creek downstream from the mine site (EC-CELK1).

\section{Water-Chemistry Sampling}

Onsite measurements of $\mathrm{pH}$, specific conductance, temperature, dissolved oxygen, and redox potential were obtained for surface and Level 3 samples. At each site the $\mathrm{pH}$ electrode calibration was checked and, when necessary, recalibrated using two buffers that bracketed the sample $\mathrm{pH}$. Samples were filtered onsite through a syringe, 0.45 micrometer filter.
Level 2 samples were collected by CDRMS personnel in acid washed, distilled water rinsed 1 liter bottles and brought to the surface for measurements of $\mathrm{pH}$, specific conductance, and redox potential. Samples were kept out of sunlight in a cooler until processing, approximately 30 to 90 minutes after collection. Level 2 samples were filtered at the surface adjacent to the Level 3 portal. For all samples, several sample aliquots were collected for determination of concentrations of inorganic constituents and redox species $\left(\mathrm{Fe}^{+2} / \mathrm{Fe}^{+3}\right)$. Container preparation and stabilization of filtered samples included an unfiltered, nitric acid acidified aliquot (RA) for totalrecoverable major cation and trace-element determinations; a filtered, nitric acid acidified aliquot (FA) for dissolved major cation and trace-element determinations; a filtered, unacidified aliquot (FU) for anion and alkalinity determinations; and a filtered, hydrochloric acid acidified aliquot for iron redox species determinations. Bottles for FA and RA aliquots were presoaked in nitric acid, rinsed in distilled water, and prerinsed with sample water. Bottles for FU aliquots were presoaked in distilled water and prerinsed with sample water. Opaque bottles for iron redox aliquots were presoaked in hydrochloric acid, rinsed in distilled water, and prerinsed with sample water. Appropriate aliquots were acidified with ultrapure acid and then stored on ice until refrigerated.

\section{Laboratory Methods}

All reagents were of a purity at least equal to the reagentgrade standards of the American Chemical Society. Doubledistilled deionized water, and redistilled acids using a subboiling purification technique (Kuehner and others, 1972), were used in all preparations. The methods and detection limit for each analysis are summarized in table 2. USGS standardreference-water samples and blanks were included with each sample suite for inductively coupled plasma atomic-emission spectroscopy (ICP-AES) and inductively coupled plasma-mass spectrometry (ICP-MS). Major cations (calcium, magnesium, potassium, and sodium) and silica and selected trace elements (aluminum, boron, barium, cadmium, copper, iron, manganese, lead, strontium, and zinc) for total-recoverable and dissolved samples were determined using a Perkin Elmer Optima $3000^{\mathrm{TM}}$ ICP-AES (Briggs, 2002). Trace elements for total-recoverable and dissolved samples were analyzed with the Elan DCRe ICP-MS using a method developed by the U.S. Geological Survey (Meier and others, 1994; Lamothe and others, 2002). This method is used to directly determine the elements in the water samples without need for any preconcentration or dilution. Elemental detection limits are in the subparts per billion range (table 2), and the working linear range is six or more orders of magnitude.

Concentrations of major anions $\left(\mathrm{Cl}^{-}, \mathrm{F}^{-}, \mathrm{NO}_{3}^{-}\right.$and $\left.\mathrm{SO}_{4}^{-}\right)$ were determined by ion chromatography (Brinton and others, 1995) using a Dionex $600^{\mathrm{TM}}$ ion chromatograph with 25 microliter sample loops. Standards were prepared from compounds of the highest commercially available purity. 
Table 1. Sample site locations.

[ft, feet; UG, underground; m, meter; coordinates are Universal Transverse Mercator (UTM) coordinate system, North American Datum of 1983, Zone 13]

\begin{tabular}{|c|c|c|c|c|}
\hline Site name & $\begin{array}{c}\text { Northing } \\
(\mathrm{m})\end{array}$ & $\begin{array}{c}\text { Easting } \\
(\mathrm{m})\end{array}$ & Description & Elevation (ft) \\
\hline EC-MSTD1 & 4305517 & 320124 & Standard Mine, Level 1-portal & 11,008 \\
\hline EC-MSTDL21 & UG & UG & $\begin{array}{l}\text { Standard Mine, Level 2-see figure } 5 \text {, } \\
\text { drips from drill hole }\end{array}$ & UG \\
\hline EC-MSTDL22 & UG & UG & $\begin{array}{l}\text { Standard Mine, Level 2-see figure 5, } \\
\text { drips along flowstone }\end{array}$ & UG \\
\hline EC-MSTDL23 & UG & UG & $\begin{array}{l}\text { Standard Mine, Level 2-see figure } 5 \text {, } \\
\text { stream from raise }\end{array}$ & UG \\
\hline EC-MSTDL24 & UG & UG & $\begin{array}{l}\text { Standard Mine, Level 2-see figure } 5 \text {, } \\
\text { drips from ore chute }\end{array}$ & UG \\
\hline EC-MSTDL25 & UG & UG & $\begin{array}{l}\text { Standard Mine, Level 2-see figure 5, } \\
\text { drips from back }\end{array}$ & UG \\
\hline EC-MSTDL26 & UG & UG & $\begin{array}{l}\text { Standard Mine, Level 2-see figure } 5 \\
\text { drips from timbered stope }\end{array}$ & UG \\
\hline EC-MSTDL31 & UG & UG & $\begin{array}{l}\text { Standard Mine, Level 3-132 ft in from portal, water flowing } \\
\text { along floor to raise }\end{array}$ & UG \\
\hline EC-MSTDL32 & UG & UG & $\begin{array}{l}\text { Standard Mine, Level 3-145 ft in from portal, water flowing } \\
\text { along floor to raise }\end{array}$ & UG \\
\hline EC-MSTDL33 & UG & UG & Standard Mine, Level 3-327 ft in from portal, drips from back & UG \\
\hline EC-MSTDL34 & UG & UG & $\begin{array}{l}\text { Standard Mine, Level 3-386 ft in from portal, water flowing } \\
\text { along floor to raise }\end{array}$ & UG \\
\hline EC-MSTDL35 & UG & UG & $\begin{array}{l}\text { Standard Mine, Level 3-639 ft in from portal, water pooled at } \\
\text { end of tunnel }\end{array}$ & UG \\
\hline EC-M11600 & 4305941 & 320667 & Standard Mine, Level 5-portal & 11,581 \\
\hline EC-S1 & 4305936 & 320610 & Seep from base of waste-rock pile below Level 5 portal & 11,510 \\
\hline EC-S08 & 4305449 & 320159 & Spring & 11,071 \\
\hline EC-CELK1 & 4302915 & 321270 & Elk Creek near confluence with Coal Creek & 9,579 \\
\hline
\end{tabular}

USGS standard-reference-water samples were used as independent quality-control standards. Alkalinity (as $\mathrm{HCO}_{3}^{-}$) was determined using an Orion $960^{\mathrm{TM}}$ autotitrator and standardized $\mathrm{H}_{2} \mathrm{SO}_{4}$ (Barringer and Johnsson, 1989). Samples were diluted as necessary to bring the analyte concentration within the optimal range of the method. Iron (II) and total iron, in filtered, $\mathrm{HCl}$-acidified samples, were determined using a modification of the FerroZine ${ }^{\mathrm{TM}}$ colorimetric method (Stookey, 1970; To and others, 1999) with a Hewlett Packard 8453 ${ }^{\mathrm{TM}}$ diode array ultraviolet/visible (UV/VIS) spectrophotometer.

Samples for analysis of oxygen and hydrogen isotopic compositions $\left(\delta^{18} \mathrm{O}, \delta^{2} \mathrm{H}\right)$ of water were collected in borosilicate glass bottles (unfiltered, unpreserved) and analyzed by the U.S. Geological Survey Stable Isotope Laboratory in Denver, Colo. Oxygen isotopic compositions were determined using a Micromass Optima with an automated $\mathrm{CO}_{2}$ equilibration technique adapted from Epstein and Mayeda (1953). Water samples were prepared for hydrogen-isotopic analyses using the zinc-reduction technique (Kendall and Coplen, 1985).
The hydrogen analyses were preformed on a Finnigan MAT 252 mass spectrometer. Values of $\delta^{18} \mathrm{O}$ and $\delta^{2} \mathrm{H}$ were relative to Vienna Standard Mean Ocean Water (VSMOW), and they have reproducibility of approximately 0.2 and 1.0 per mil, respectively.

\section{Quality Assurance and Quality Control}

Quality control included replicate samples, field-equipment blanks, analyses by alternative methods, and calculation of charge imbalance. Replicate samples are two field-collected samples that are considered to be essentially identical in composition and are used to estimate variability in environmental data. Replicate samples were collected immediately following the environmental sample. Each replicate sample was processed through all the steps of the environmental sample using a new filter and clean equipment. Replicate samples were analyzed at the same time using the same instruments as the other 


\section{Standard Mine Level 2}

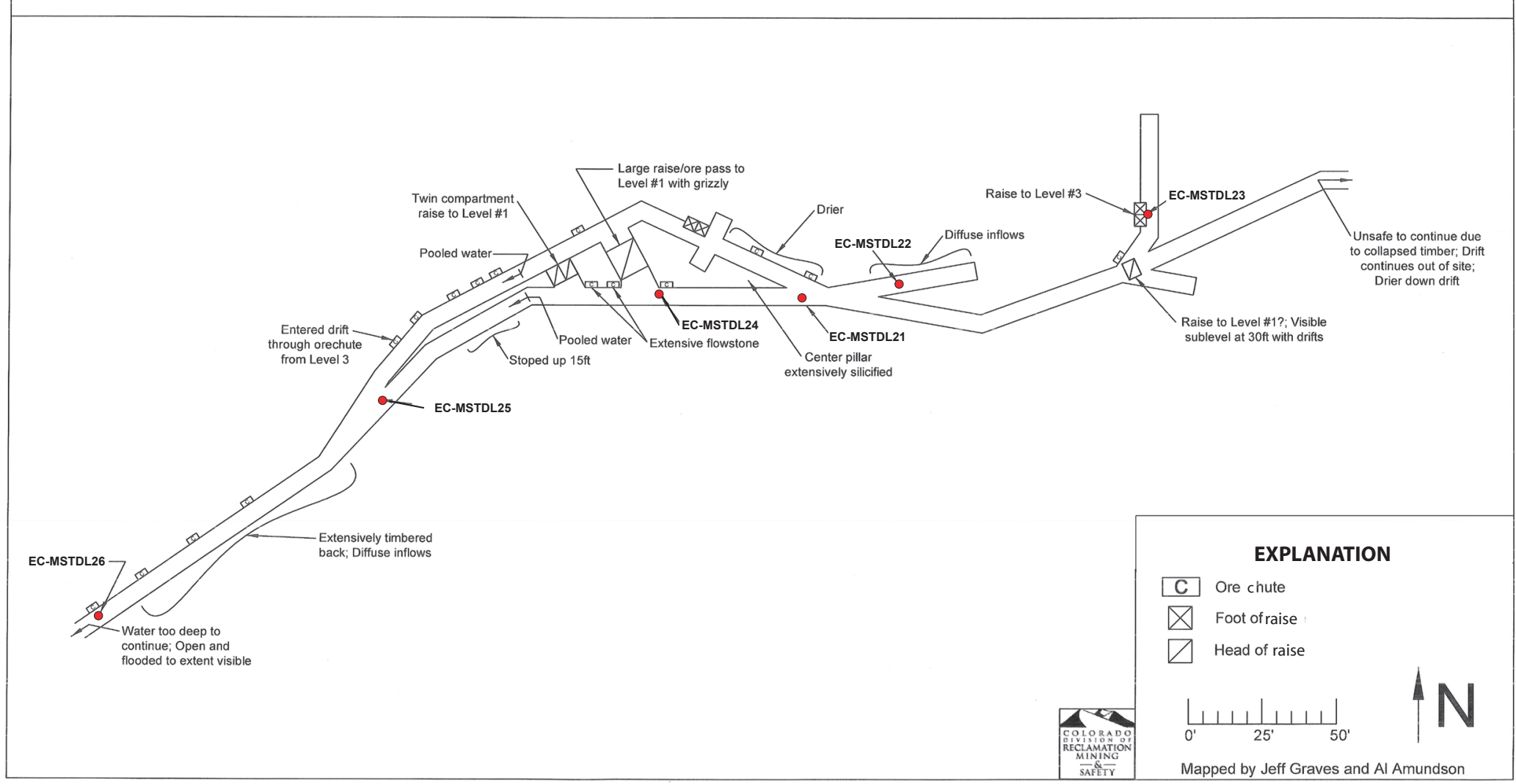

Figure 5. Level 2 of the Standard Mine showing sample sites. Mine map courtesy of Colorado Division of Reclamation Mining and Safety (Graves, 2009). 


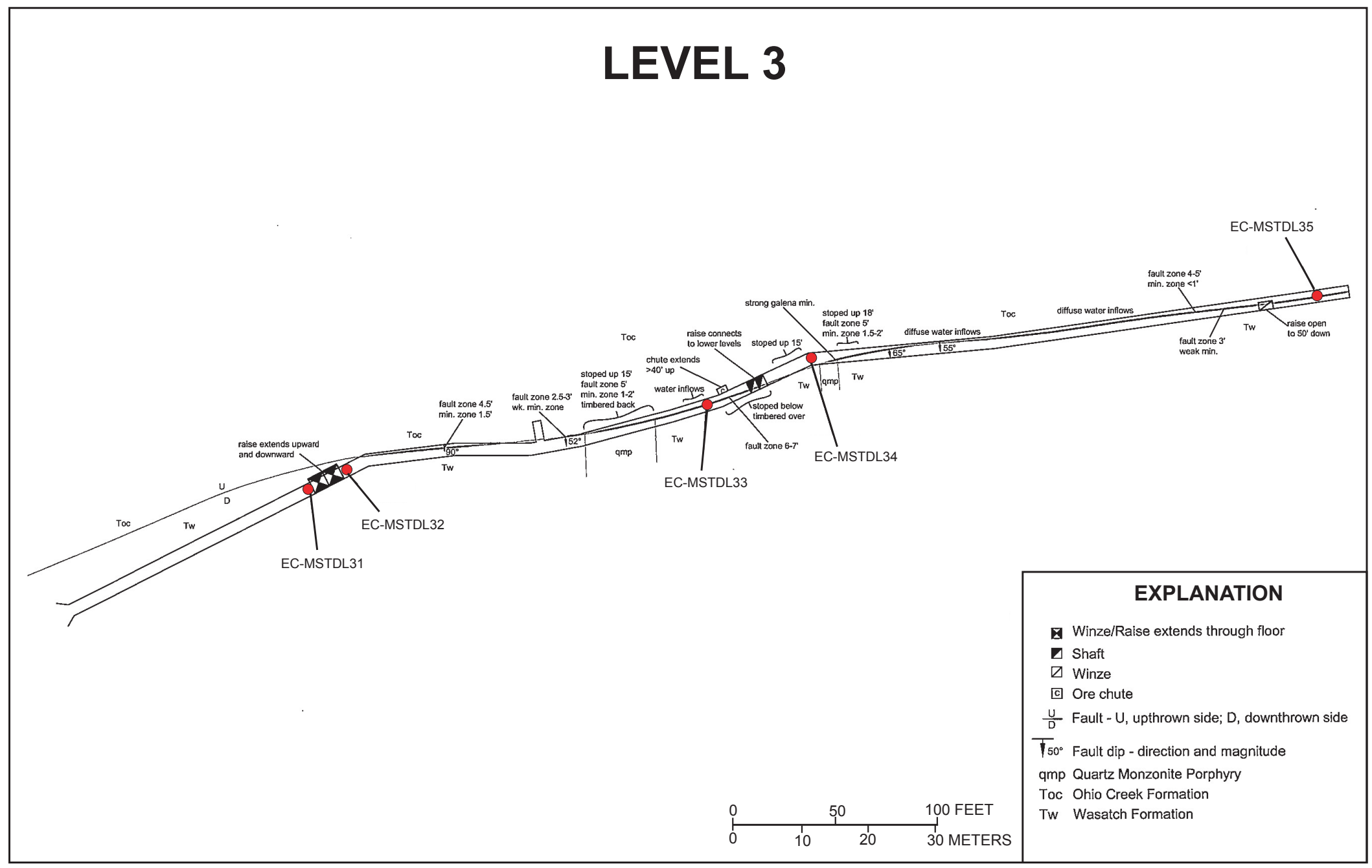

Figure 6. Level 3 of the Standard Mine showing sample sites. Mine map courtesy of Colorado Division of Reclamation, Mining, and Safety (Colorado Division of Reclamation Mining and Safety, 2007). min., mineralized or mineralization; wk. min., weakly mineralized. 
Table 2. Methods of analysis and detection limits.

$[\mathrm{mg} / \mathrm{L}$, milligram per liter; $\mu \mathrm{g} / \mathrm{L}$, microgram per liter; IC, ion chromatography; ICP-MS, inductively coupled plasmamass spectrometry; ICP-AES, inductively coupled plasma-atomic emission spectroscopy]

\begin{tabular}{|c|c|c|c|c|c|}
\hline Element & Detection limit & Method & Element & Detection limit & Method \\
\hline $\mathrm{Ag}$ & $3 \mu \mathrm{g} / \mathrm{L}$ & ICP-MS & $\mathrm{Mn}$ & $10 \mu \mathrm{g} / \mathrm{L}$ & ICP-AES \\
\hline $\mathrm{Al}$ & $20 \mu \mathrm{g} / \mathrm{L}$ & ICP-AES & $\mathrm{Mn}$ & $1 \mu \mathrm{g} / \mathrm{L}$ & ICP-MS \\
\hline $\mathrm{Al}$ & $20 \mu \mathrm{g} / \mathrm{L}$ & ICP-MS & Mo & $2 \mu \mathrm{g} / \mathrm{L}$ & ICP-MS \\
\hline As & $10 \mu \mathrm{g} / \mathrm{L}$ & ICP-MS & $\mathrm{Na}$ & $0.1 \mathrm{mg} / \mathrm{L}$ & ICP-AES \\
\hline B & $5 \mu \mathrm{g} / \mathrm{L}$ & ICP-AES & $\mathrm{Nb}$ & $2 \mu \mathrm{g} / \mathrm{L}$ & ICP-MS \\
\hline $\mathrm{Ba}$ & $1 \mu \mathrm{g} / \mathrm{L}$ & ICP-AES & $\mathrm{Nd}$ & $0.1 \mu \mathrm{g} / \mathrm{L}$ & ICP-MS \\
\hline $\mathrm{Ba}$ & $2 \mu \mathrm{g} / \mathrm{L}$ & ICP-MS & $\mathrm{Ni}$ & $2 \mu \mathrm{g} / \mathrm{L}$ & ICP-MS \\
\hline $\mathrm{Be}$ & $0.5 \mu \mathrm{g} / \mathrm{L}$ & ICP-MS & $\mathrm{NO}_{3}^{-}$ & $0.05 \mathrm{mg} / \mathrm{L}$ & IC \\
\hline $\mathrm{Bi}$ & $2 \mu \mathrm{g} / \mathrm{L}$ & ICP-MS & $\mathrm{P}$ & $100 \mu \mathrm{g} / \mathrm{L}$ & ICP-MS \\
\hline $\mathrm{Ca}$ & $0.1 \mathrm{mg} / \mathrm{L}$ & ICP-AES & $\mathrm{Pb}$ & $10 \mu \mathrm{g} / \mathrm{L}$ & ICP-AES \\
\hline $\mathrm{Cd}$ & $5 \mu \mathrm{g} / \mathrm{L}$ & ICP-AES & $\mathrm{Pb}$ & $0.5 \mu \mathrm{g} / \mathrm{L}$ & ICP-MS \\
\hline $\mathrm{Cd}$ & $0.2 \mu \mathrm{g} / \mathrm{L}$ & ICP-MS & $\operatorname{Pr}$ & $0.1 \mu \mathrm{g} / \mathrm{L}$ & ICP-MS \\
\hline $\mathrm{Ce}$ & $0.1 \mu \mathrm{g} / \mathrm{L}$ & ICP-MS & $\mathrm{Rb}$ & $0.1 \mu \mathrm{g} / \mathrm{L}$ & ICP-MS \\
\hline $\mathrm{Cl}^{-}$ & $0.1 \mathrm{mg} / \mathrm{L}$ & IC & $\mathrm{Sb}$ & $3 \mu \mathrm{g} / \mathrm{L}$ & ICP-MS \\
\hline Co & $0.2 \mu \mathrm{g} / \mathrm{L}$ & ICP-MS & $\mathrm{Sc}$ & $1 \mu \mathrm{g} / \mathrm{L}$ & ICP-MS \\
\hline $\mathrm{Cr}$ & $3 \mu \mathrm{g} / \mathrm{L}$ & ICP-MS & $\mathrm{Se}$ & $10 \mu \mathrm{g} / \mathrm{L}$ & ICP-MS \\
\hline Cs & $0.2 \mu \mathrm{g} / \mathrm{L}$ & ICP-MS & $\mathrm{SiO}_{2}$ & $0.1 \mathrm{mg} / \mathrm{L}$ & ICP-AES \\
\hline $\mathrm{Cu}$ & $10 \mu \mathrm{g} / \mathrm{L}$ & ICP-AES & $\mathrm{SO}_{4}^{-}$ & $0.05 \mathrm{mg} / \mathrm{L}$ & IC \\
\hline $\mathrm{Cu}$ & $5 \mu \mathrm{g} / \mathrm{L}$ & ICP-MS & $\mathrm{SO}_{4}^{-}$ & $1 \mathrm{mg} / \mathrm{L}$ & ICP-AES \\
\hline Dy & $0.05 \mu \mathrm{g} / \mathrm{L}$ & ICP-MS & $\mathrm{Sm}$ & $0.1 \mu \mathrm{g} / \mathrm{L}$ & ICP-MS \\
\hline Er & $0.05 \mu \mathrm{g} / \mathrm{L}$ & ICP-MS & $\mathrm{Sr}$ & $1 \mu \mathrm{g} / \mathrm{L}$ & ICP-AES \\
\hline $\mathrm{Eu}$ & $0.05 \mu \mathrm{g} / \mathrm{L}$ & ICP-MS & $\mathrm{Sr}$ & $5 \mu \mathrm{g} / \mathrm{L}$ & ICP-MS \\
\hline $\mathrm{F}^{-}$ & $0.1 \mu \mathrm{g} / \mathrm{L}$ & IC & $\mathrm{Ta}$ & $0.2 \mu \mathrm{g} / \mathrm{L}$ & ICP-MS \\
\hline $\mathrm{Fe}$ & $20 \mu \mathrm{g} / \mathrm{L}$ & ICP-AES & $\mathrm{Tb}$ & $0.05 \mu \mathrm{g} / \mathrm{L}$ & ICP-MS \\
\hline $\mathrm{Fe}$ & $2 \mu \mathrm{g} / \mathrm{L}$ & FerroZine & Th & $2 \mu \mathrm{g} / \mathrm{L}$ & ICP-MS \\
\hline $\mathrm{Fe}(\mathrm{II})$ & $2 \mu \mathrm{g} / \mathrm{L}$ & FerroZine & $\mathrm{Ti}$ & $2 \mu \mathrm{g} / \mathrm{L}$ & ICP-MS \\
\hline $\mathrm{Ga}$ & $0.5 \mu \mathrm{g} / \mathrm{L}$ & ICP-MS & $\mathrm{Tl}$ & $2 \mu \mathrm{g} / \mathrm{L}$ & ICP-MS \\
\hline $\mathrm{Gd}$ & $0.05 \mu \mathrm{g} / \mathrm{L}$ & ICP-MS & $\mathrm{Tm}$ & $0.05 \mu \mathrm{g} / \mathrm{L}$ & ICP-MS \\
\hline $\mathrm{Ge}$ & $0.5 \mu \mathrm{g} / \mathrm{L}$ & ICP-MS & $\mathrm{U}$ & $1 \mu \mathrm{g} / \mathrm{L}$ & ICP-MS \\
\hline Но & $0.05 \mu \mathrm{g} / \mathrm{L}$ & ICP-MS & V & $5 \mu \mathrm{g} / \mathrm{L}$ & ICP-MS \\
\hline $\mathrm{K}$ & $0.1 \mu \mathrm{g} / \mathrm{L}$ & ICP-AES & $\mathrm{W}$ & $5 \mu \mathrm{g} / \mathrm{L}$ & ICP-MS \\
\hline $\mathrm{K}$ & $300 \mu \mathrm{g} / \mathrm{L}$ & ICP-MS & $\mathrm{Y}$ & $0.1 \mu \mathrm{g} / \mathrm{L}$ & ICP-MS \\
\hline $\mathrm{La}$ & $0.04 \mu \mathrm{g} / \mathrm{L}$ & ICP-MS & $\mathrm{Yb}$ & $0.05 \mu \mathrm{g} / \mathrm{L}$ & ICP-MS \\
\hline $\mathrm{Li}$ & $1 \mu \mathrm{g} / \mathrm{L}$ & ICP-MS & $\mathrm{Zn}$ & $20 \mu \mathrm{g} / \mathrm{L}$ & ICP-AES \\
\hline $\mathrm{Lu}$ & $0.5 \mu \mathrm{g} / \mathrm{L}$ & ICP-MS & $\mathrm{Zn}$ & $0.5 \mu \mathrm{g} / \mathrm{L}$ & ICP-MS \\
\hline $\mathrm{Mg}$ & $0.1 \mathrm{mg} / \mathrm{L}$ & ICP-AES & $\mathrm{Zr}$ & $0.5 \mu \mathrm{g} / \mathrm{L}$ & ICP-MS \\
\hline
\end{tabular}


samples collected during the same sampling trip. Analytical results of replicate samples are included in tables 3 and 4, and follow the corresponding water sample (sample name ending with R). Most major, minor, and trace-element replicate concentrations are within \pm 10 percent of the corresponding water-chemistry sample.

A field-equipment blank is a sample prepared using deionized water passed through all the sampling and processing equipment. This type of sample is used to check for the potential contamination of the water-chemistry samples during collection, processing, handling, and analysis. Analytical results are included in tables 3 and 4, designated EB-06 and EB-07 (equipment blank). All analytes were below analytical detection limits except for bicarbonate alkalinity, which was consistently measured at $2 \mathrm{mg} / \mathrm{L}$, just above the reporting limit.

Concentrations of cations were determined by ICP-AES and ICP-MS, and if concentrations of trace elements were at least three times the detection limit, good agreement between ICP-AES and ICP-MS results was observed (fig. 7). Barium, manganese, and strontium were chosen for this comparison because the range in concentrations of these elements was within the working range of both analytical techniques.

Data for all samples with complete analyses were checked using the computer program WATEQ4F (Ball and Nordstrom, 1991) for charge imbalance (C.I.), using the following calculation:

$$
\text { C.I. }(\text { percent })=\frac{100 *(\text { sum cations-sum anions })}{(\text { sum cations }+ \text { sum anions })}
$$

where sum cations is the sum of the cations in milliequivalents per liter, and sum anions is the sum of the anions in milliequivalents per liter. The percent-charge imbalance reflects how well the major anions and cations balance and usually is an independent measure of the accuracy of the analytical techniques. The percent-charge imbalance was low (less than 10 percent) for all samples (table 3 ).

\section{Water Chemistry}

All water chemistry data are reported in tables 3,4 , and 5. Table 3 includes field parameters and constituent concentrations measured by ion chromatography, ICP-AES, alkalinity titration, and FerroZine ${ }^{\mathrm{TM}}$ colorimetric method. Table 4 presents the ICPMS results. Figures $8 \mathrm{~A}$ and $8 \mathrm{~B}$ display the comparison of $\mathrm{pH}$ and specific conductance for the 10 sites that were sampled in August 2006 and July 2009. For most samples, $\mathrm{pH}$ and specific conductance were similar for the two different years. The one site with a greater than 20 percent difference in specific conductance is site ECS1, the series of small seeps at the toe of the waste-rock pile below the Level 5 portal. Water seeps from multiple locations along the onemeter section at the toe of the waste pile such that heterogeneity in results from the different sampling occurrences likely in part reflects heterogeneity of the diffuse seep. Figure 8C and
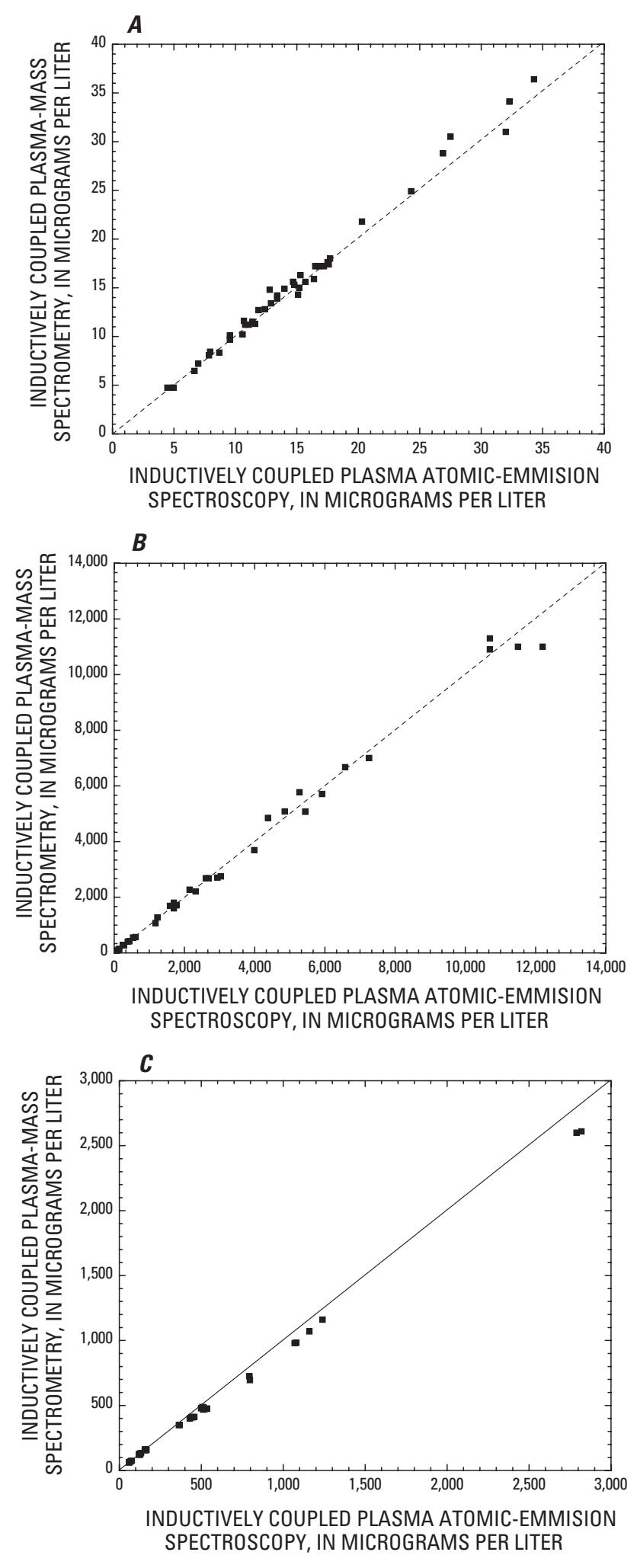

Figure 7. Comparison of analytical results by inductively coupled plasma atomic-emission spectroscopy and inductively coupled plasma-mass spectrometry with $(A)$ barium concentration; $(B)$ manganese concentration; and $(C)$ strontium concentration. Diagonal line is 1:1 correspondence and dashed lines indicate 10-percent variation. 

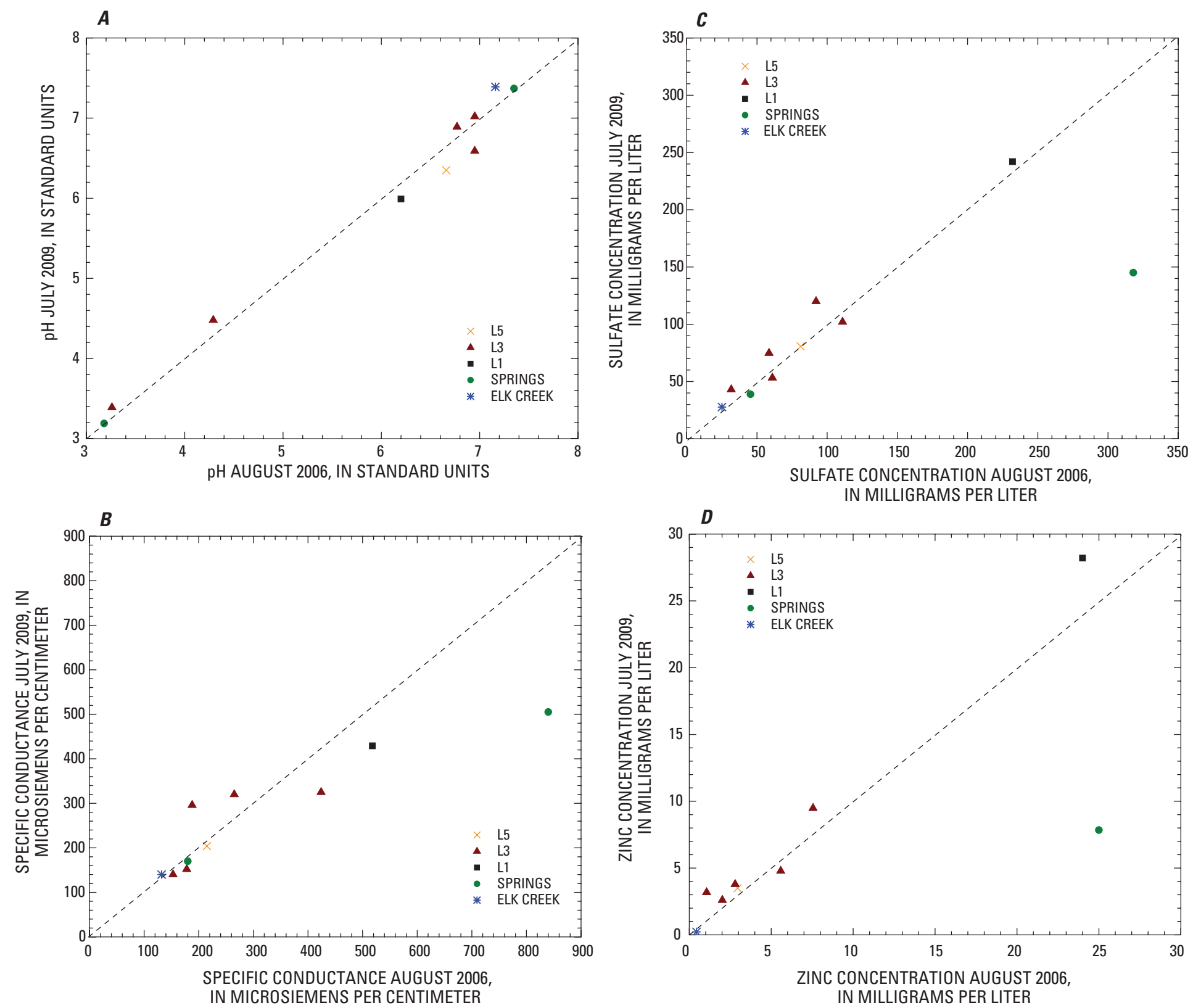

Figure 8. Comparison of 2006 and 2009 chemical results with $(A) \mathrm{pH} ;(B)$ specific conductance; $(C)$ sulfate concentration; and $(D)$ zinc concentration. 
Table 5. Water isotopic analyses.

$[\mathrm{R}$, replicate sample $]$

\begin{tabular}{lccc}
\hline \multicolumn{1}{c}{ Site } & $\begin{array}{c}\text { Date } \\
\text { collected }\end{array}$ & $\begin{array}{c}\boldsymbol{\delta}^{18} \mathbf{0} \\
\text { (per mil) }\end{array}$ & $\begin{array}{c}\delta^{2} \mathbf{H} \\
\text { (per mil) }\end{array}$ \\
\hline ECMSTD1-10 & $7 / 20 / 2009$ & -16.74 & -121.7 \\
ECMSTDL 21-01 & $7 / 22 / 2009$ & -15.72 & -113.3 \\
ECMSTDL 22-01 & $7 / 22 / 2009$ & -15.87 & -116.0 \\
ECMSTDL 23-01 & $7 / 22 / 2009$ & -16.48 & -119.8 \\
ECMSTDL 24-01 & $7 / 22 / 2009$ & -16.78 & -122.2 \\
ECMSTDL 25-01 & $7 / 22 / 2009$ & -16.69 & -121.8 \\
ECMSTDL 26-01 & $7 / 22 / 2009$ & -16.66 & -120.3 \\
ECMSTDL-31-02 & $7 / 21 / 2009$ & -16.58 & -121.6 \\
ECMSTDL-32-02 & $7 / 21 / 2009$ & -16.93 & -126.3 \\
ECMSTDL-33-02 & $7 / 21 / 2009$ & -16.92 & -126.5 \\
ECMSTDL-34-02 & $7 / 21 / 2009$ & -16.92 & -123.1 \\
ECMSTDL-35-02 & $7 / 21 / 2009$ & -16.70 & -123.0 \\
ECM11600-02 & $7 / 21 / 2009$ & -16.71 & -121.3 \\
ECM11600-02R & $7 / 21 / 2009$ & -16.69 & -122.1 \\
ECCELK1-09 & $7 / 22 / 2009$ & -17.03 & -125.7 \\
ECCELK1-09R & $7 / 22 / 2009$ & -17.08 & -125.8 \\
ECS1-02 & $7 / 21 / 2009$ & -16.73 & -122.0 \\
ECS8-05 & $7 / 22 / 2009$ & -17.03 & -124.1 \\
\hline
\end{tabular}

8D display the comparison of sulfate and zinc for the 10 sites that were sampled in August 2006 and July 2009. Overall, most samples have similar concentrations of zinc and sulfate except for, again, the EC-S1 seep sample. The concentrations of both zinc and sulfate substantially are lower (7.8 and 25 $\mathrm{mg} / \mathrm{L} ; 145$ and $318 \mathrm{mg} / \mathrm{L}$, respectively) in 2009 compare to 2006.

The six Level 2 samples vary in $\mathrm{pH}$ from 3.24 to 7.53 and specific conductance from 303 to 720 microsiemens per centimenter. Only one sample had a $\mathrm{pH}$ value of less than 6 , sample ECMSTDL24-01. This sample was collected below a dripping ore chute, near the large raise that descends to Level 1 (fig. 5 and 9). Measured dissolved oxygen concentrations for Level 3 samples ranged from 7.5 to $8.5 \mathrm{mg} / \mathrm{L}$. Redox measurements for Level 2 and Level 3 samples ranged from 0.302 to 0.717 volts. The dissolved oxygen and redox determinations show that these underground samples are well oxygenated and would be classified as oxic waters.

Dissolved concentrations of sulfate, calcium, magnesium, manganese, zinc, and cadmium in Level 2 samples approach or are greater than concentrations of these constituents in the Level 1 portal effluent and tend to be substantially greater than concentrations in samples from Level 3 (fig. 9, 10A-10F, and 11). Samples ECMSTDL22-01 and ECMSTDL24-01 have the highest concentrations of these constituents with the exception of calcium in sample ECMSTDL21-01.

Sample ECMSTDL24-01 also has elevated dissolved concentrations of copper $(1.5 \mathrm{mg} / \mathrm{L})$ and lead $(0.91 \mathrm{mg} / \mathrm{L})$ compared to other Level 2 samples. Two Level 3 samples ECMSTDL31-02 and ECMSTDL32-02 also have elevated dissolved concentrations of copper (1.6 and $1.1 \mathrm{mg} / \mathrm{L}$, respectively) and lead (2.1 and $2.3 \mathrm{mg} / \mathrm{L}$ respectively). These three samples are the most acidic ( $\mathrm{pH}$ ranging from 3.24 to 4.48) underground samples collected. Copper and lead concentrations in waters tend to decrease with increasing $\mathrm{pH}$ because these elements partition onto iron precipitates.

As observed in our 2006 study (Manning and other, 2008a), zinc and cadmium covary in the mine waters (fig. 12) with the zinc to cadmium ratio between 85 and 160 . This is consistent with a common source, sphalerite $[(\mathrm{Zn}, \mathrm{Fe}) \mathrm{S}$; Fleischer, 1955]. Cadmium can substitute for zinc in the sphalerite crystal lattice because its atomic size and charge are similar to that of zinc. Sphalerite was mined at this deposit, and is present in waste-rock piles and within the mine.

Elevated concentrations of lead and copper are consistent with breakdown of the other ore minerals, argentiferous galena and chalcopyrite.

These ore minerals occur within unmined portions of the mineralized vein system, within plugged ore chutes, and in muck piles in the underground mine workings. Figure 13 is a photograph taken in July 2009 of an ore chute along Level 3 with pile of mined material below it. The material in the pile is coated with brown-colored material, iron oxyhydroxides such as goethite $[\mathrm{FeO}(\mathrm{OH})]$ and plumbojarosite $\left[\mathrm{PbFe}_{6}\left(\mathrm{SO}_{4}\right)_{4}(\mathrm{OH})_{12}\right]$ which are secondary iron-rich phases that form by the oxidation of sulfides. The gray material in the photograph is exposed material in the interior of the pile below the brown outer layer and contains fragments of galena and quartz, minor pyrite along with secondary lead mineral phases. Other similar piles are present along Level 3.

Sulfide mineralization was observed within veins along various portions of the drift on Level 3, but was most notable and extensive in the area surrounding the center raise connecting Levels 2 and 3. Muck piles along the floor in Level 3 near the center raise, as shown in figure 13, were composed of substantial unoxidized vein material consisting of pyrite, sphalerite, and galena. Similar vein material was noted within the muck pile above draw points into Level 2. Stoping between Levels 2 and 3 in the vicinity of the center raise occurred over nearly the entire vertical section and extended perpendicular to the vein in excess of 10 feet in some areas suggesting that mineralization was more widespread than on Level 3. Vein mineralization on Level 2 was not as discernable as on Level 3 because of the extensive mine timbering and thick-flowstone deposits covering the ribs and back. Mineralization appeared to be confined to areas of stoping surrounding the center raise and extending towards the portal. Numerous ore chutes filled with sulfide ore and muck piles of sulfide-rich ore were observed along the drift in Level 2 in the vicinity of 


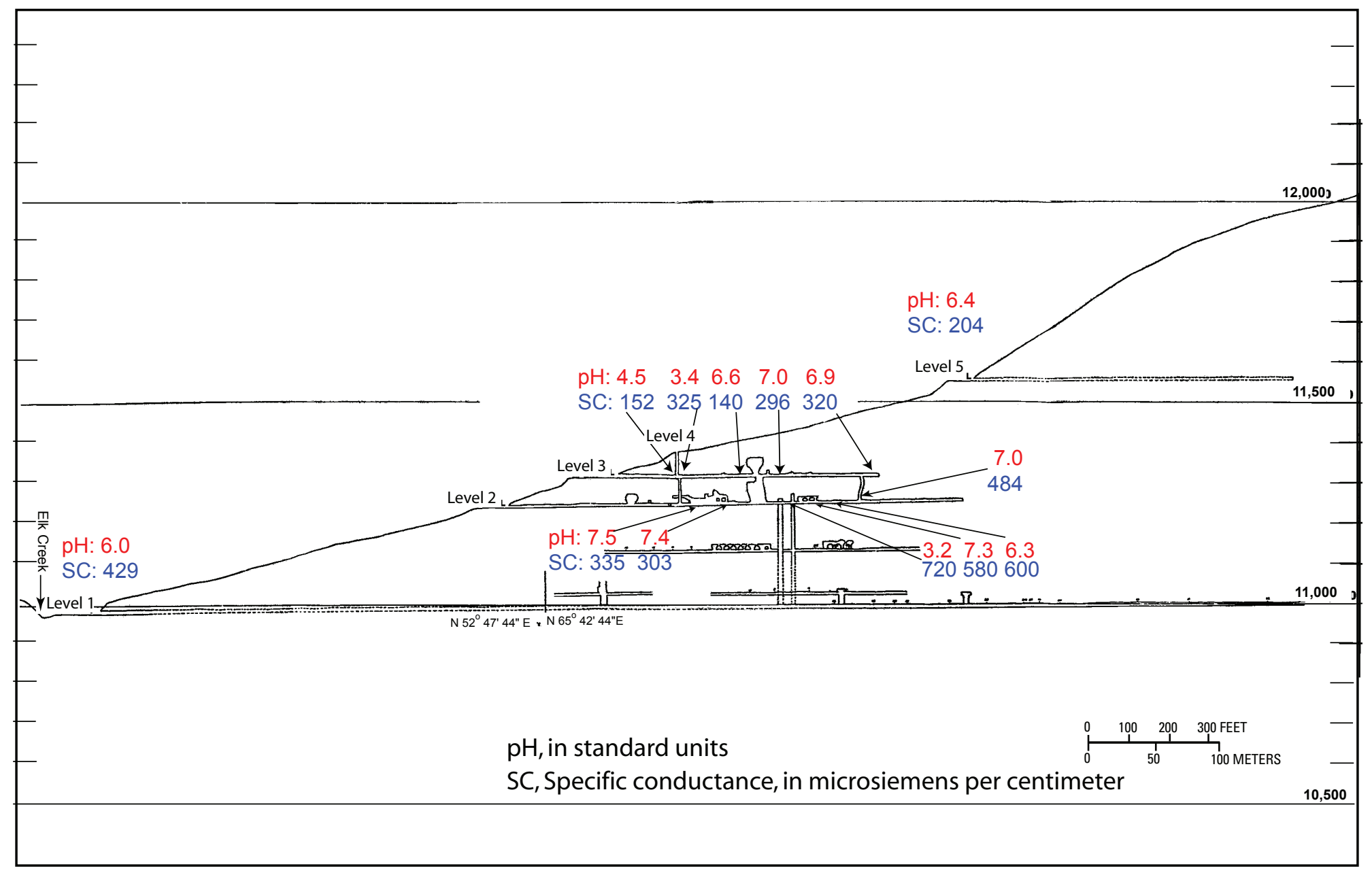

Figure 9. Cross-sectional view of the Standard Mine workings with sample $\mathrm{pH}$ and specific conductance (SC). Specific conductance in microsiemens per centimeter and pH in standard units. Level 2 and Level 3 approximate sample location projected on cross section from mine tunnel maps (fig. 5 and 6 ). 

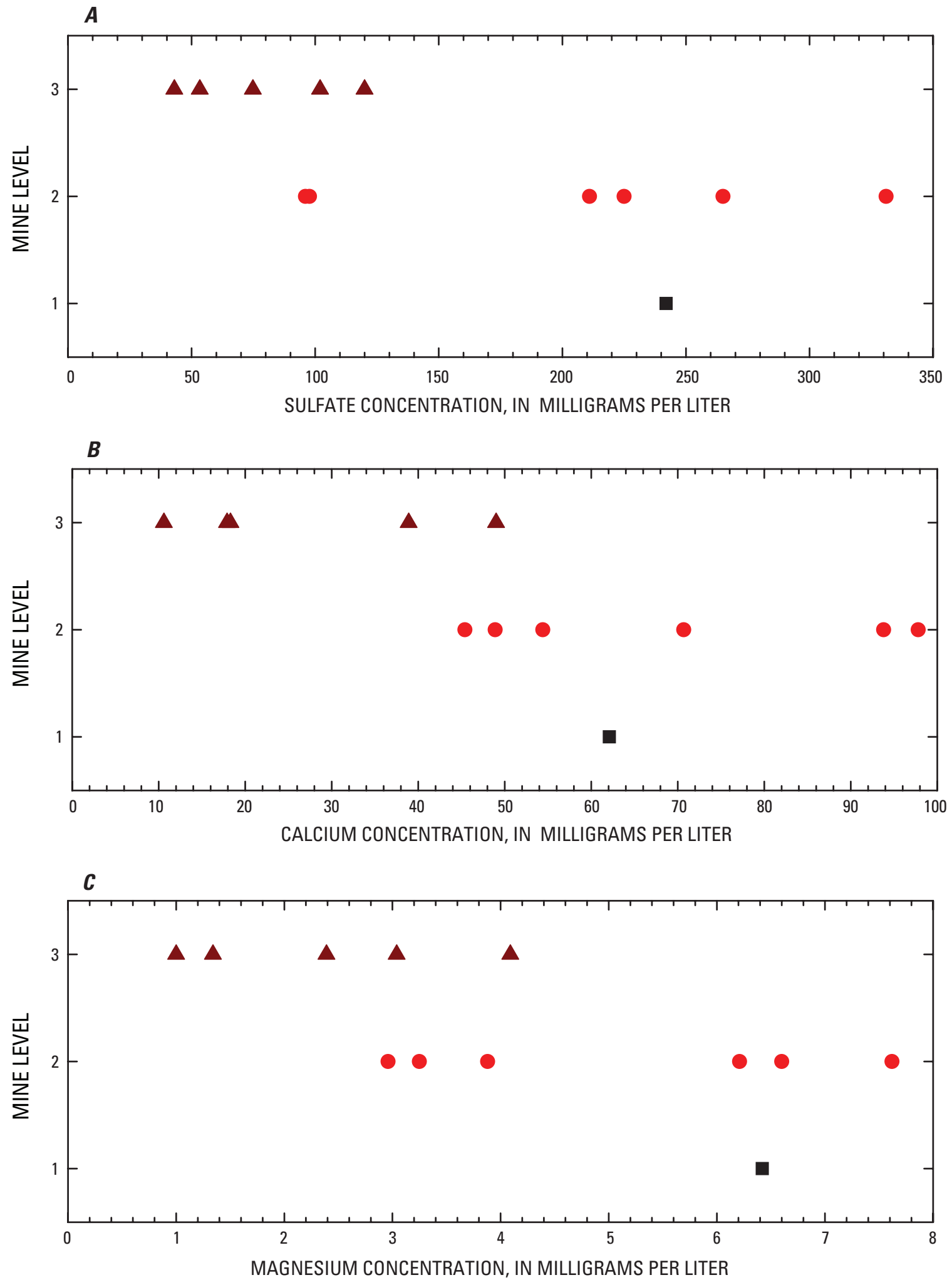

Figure 10. Sample site level and concentration of $(A)$ sulfate; $(B)$ calcium; $(C)$ magnesium; $(D)$ manganese; $(E)$ zinc; and $(F)$ cadmium in milligram per liter. 

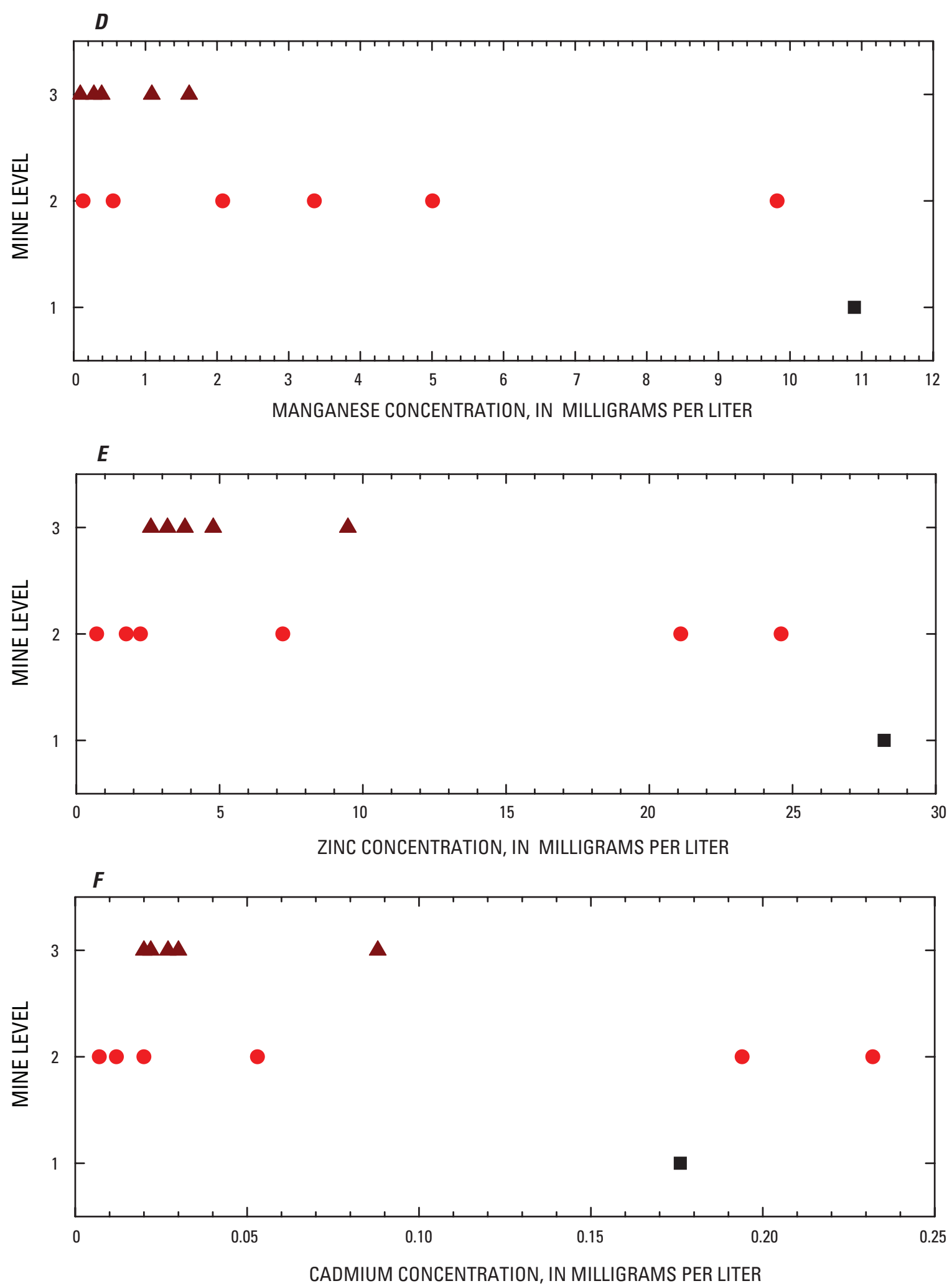

Figure 10. Diagram showing sample site level and concentration of $(A)$ sulfate; $(B)$ calcium; $(C)$ magnesium; $(D)$ manganese; $(E)$ zinc; and $(F)$ cadmium in milligram per liter-Continued 


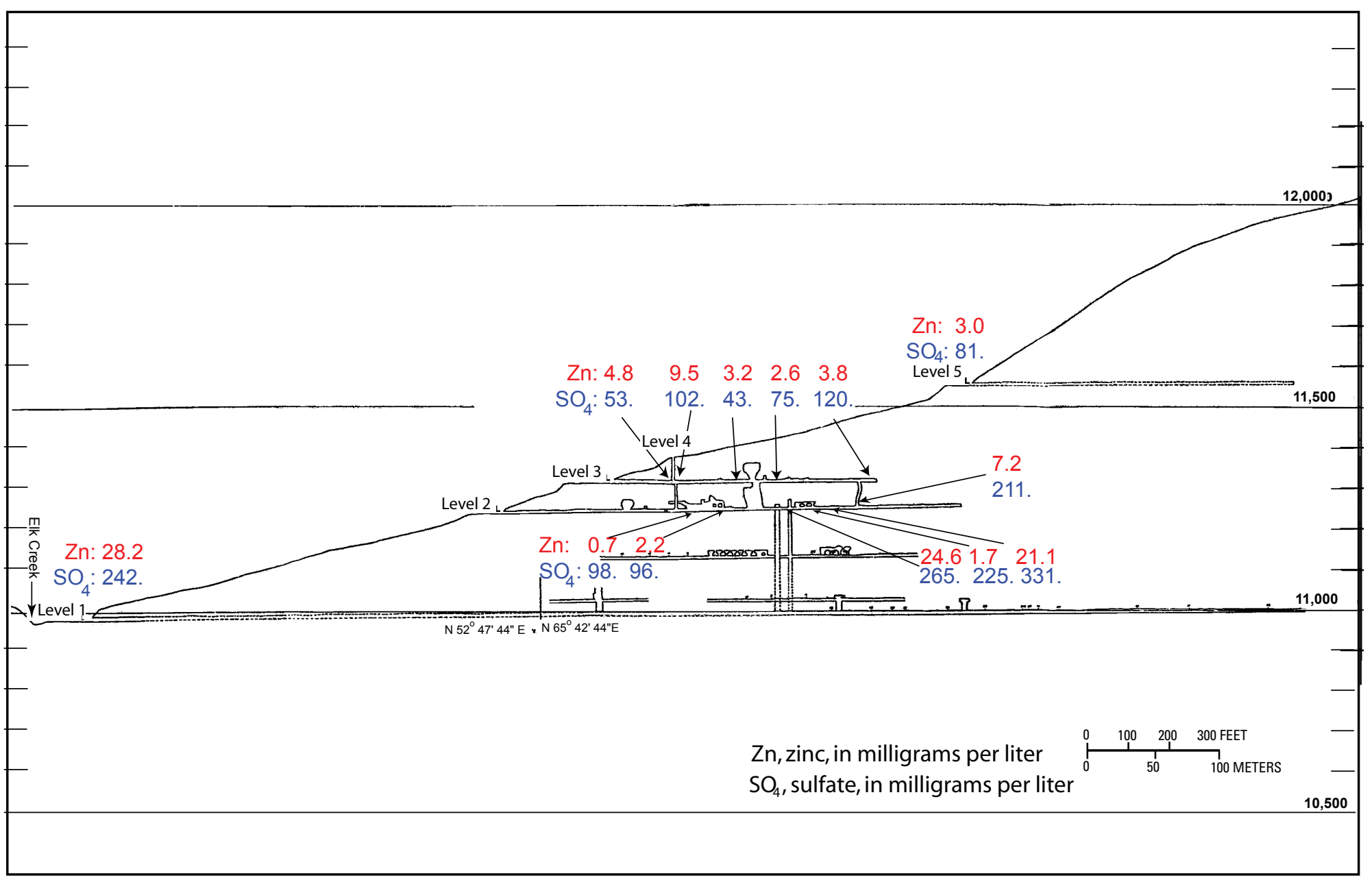

Figure 11. Cross-sectional view of the Standard Mine workings with sample sulfate and zinc concentration. Level 2 and Level 3 approximate sample location projected on cross section from mine tunnel maps (fig. 5 and 6 ). 


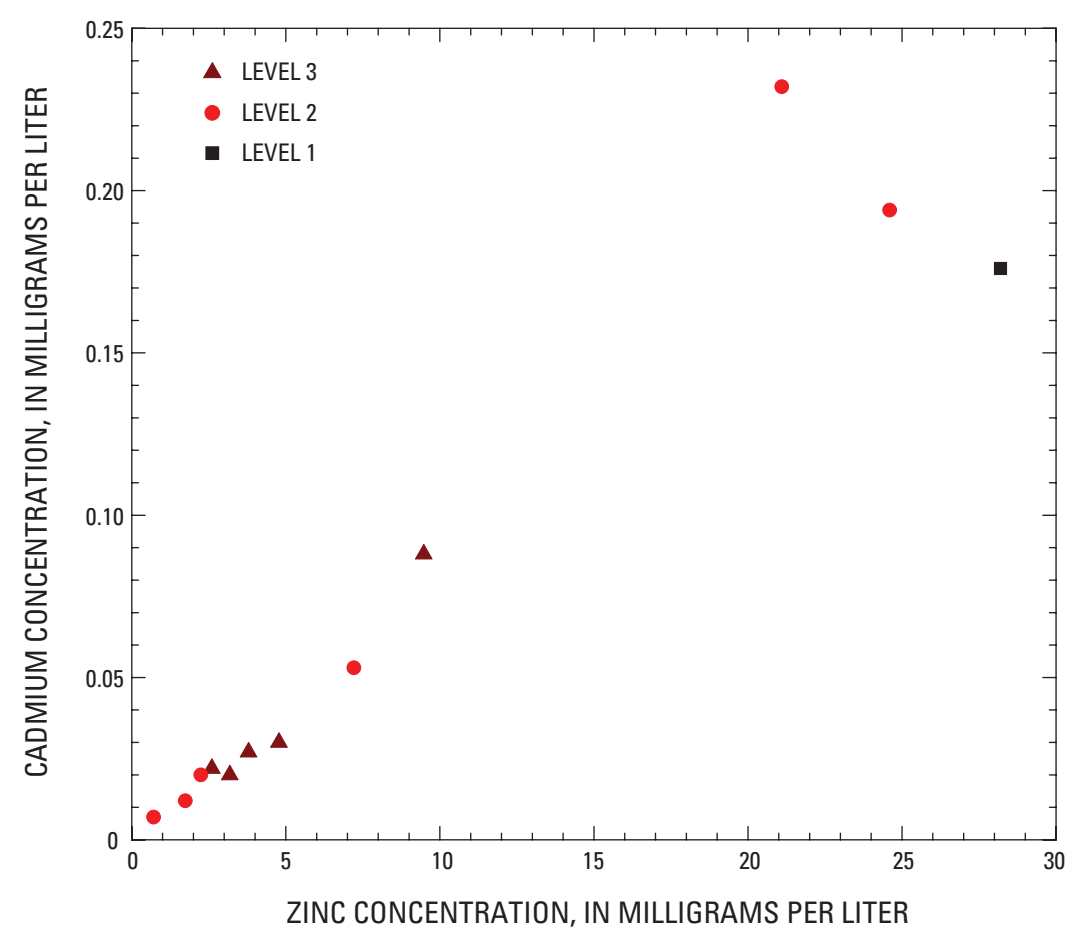

Figure 12. Zinc concentration in relation to cadmium concentration.

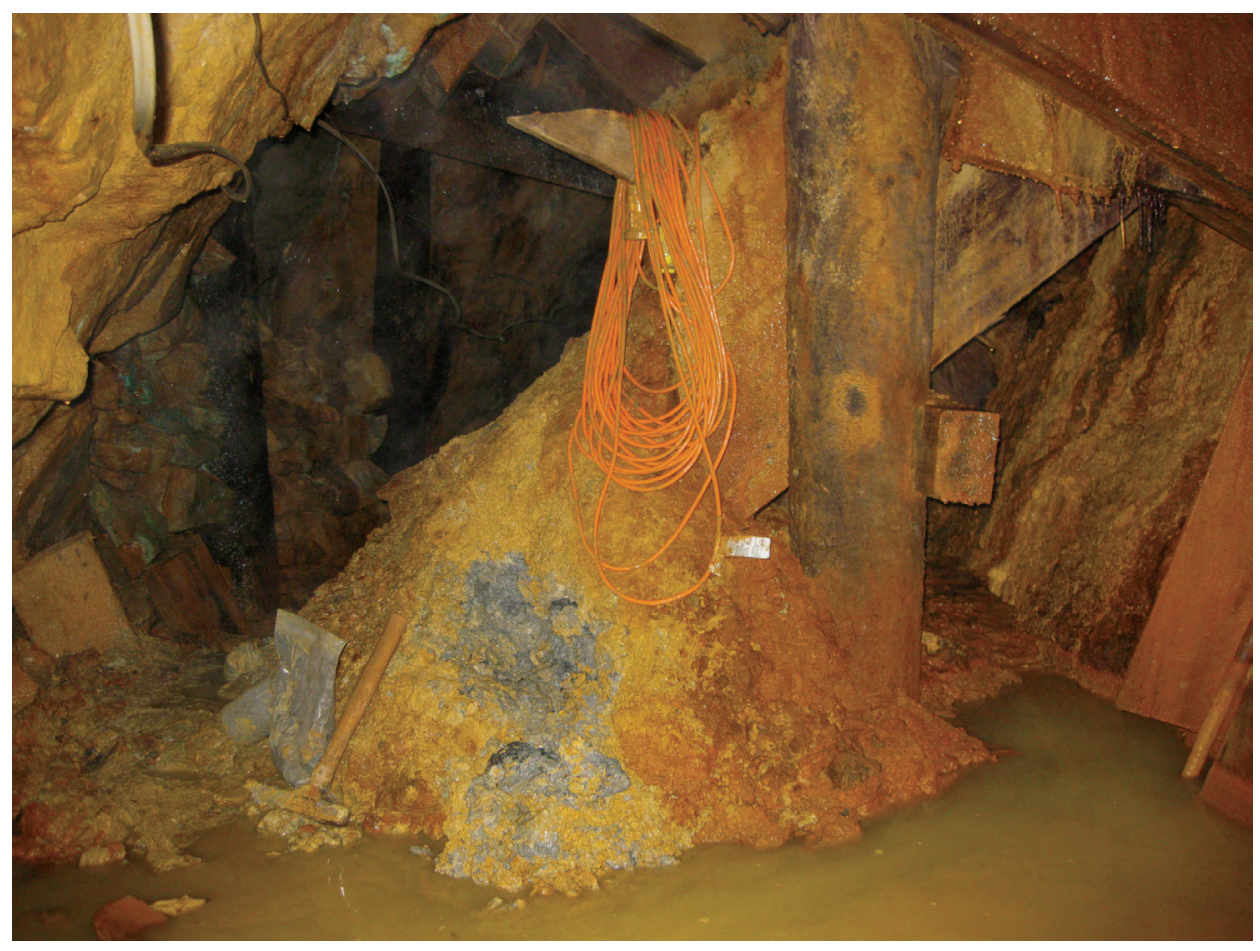

Figure 13. Ore chute with pile of mined material below, Standard Mine Level 3. Browncolored material on pile primarily consists of goethite $[\mathrm{FeO}(\mathrm{OH})]$ and plumbojarosite $\left[\mathrm{PbFe}_{6}\left(\mathrm{SO}_{4}\right)_{4}(\mathrm{OH})_{12}\right]$ which are secondary iron-rich phases that form by the oxidation of sulfides. Gray color in photograph is exposed material below brown surface containing fragments of galena and quartz with minor pyrite as well as secondary lead mineral phases and goethite. 


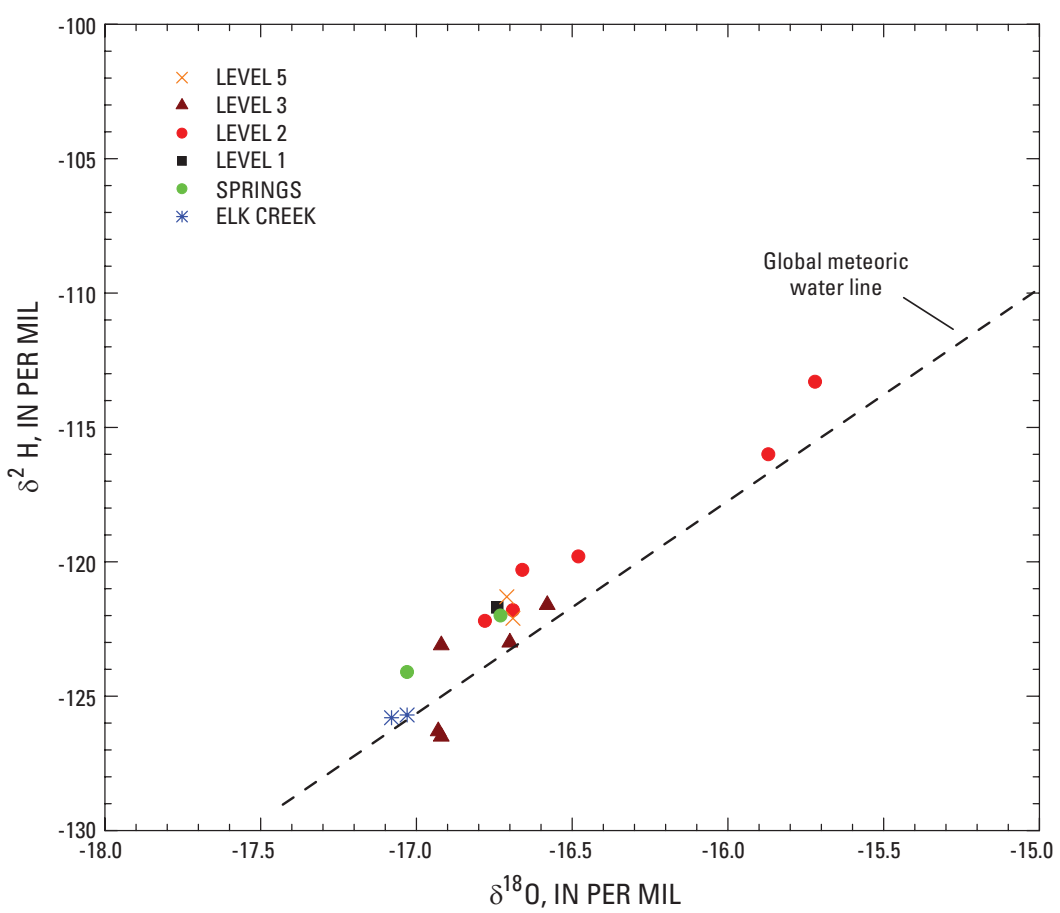

Figure 14. Hydrogen isotopic composition $\left(\delta^{2} \mathrm{H}\right)$ in relation to oxygen isotopic composition $\left(\delta^{18} 0\right)$ of waters and the global meteoric water line.

the center raise. Additional detailed observations from Level 2 are described in Graves, 2009.

The oxygen and hydrogen isotopic compositions of the 2009 water samples plot along with the global meteoric water line consistent with precipitation being the dominant control of the isotopic compositions (fig. 14). Overall, the isotopic compositions of Level 1, Level 3, and Level 5 waters are similar to the 2006 values. Manning and others (2008a) concluded that water entering into and discharging from the Standard Mine largely is composed of water that is less than a year old. This residence time was based on tritium age determinations and the seasonal signature of time series oxygen and hydrogen isotopic compositions of water discharging from the Level 1 portal. Manning and others (2008a) also showed that in general the oxygen and hydrogen isotopic compositions of Level 3 and Level 5 waters became isotopic lighter with distance into the mine consistent with overburden thickness being a first-order control of groundwater-residence time. Level 2 oxygen and hydrogen isotopic compositions of the 2009 water samples overlap Level 3 and Level 5 isotopic compositions (fig. 14), but some samples (sites ECMSTDL21 and ECMSTDL 22) have distinctly heavier isotopic compositions. Spatially, these two samples were collected between the other Level 2 samples (fig. 4). This spatial distribution is in contrast to spatial trends observed in 2006 along Level 3 and Level 5 which suggests that overburden thickness is not the dominant control on residence time for Level 2 waters. Between Level 2 and Level 3 extensive mine excavation has occurred, including extensive stoping, numerous ore chutes, and at least 3 raises (Graves, 2009; and fig. 2, 4, and 5). These excavations likely alter the natural flow paths and may provide a conduit for groundwater flow.

\section{Summary and Conclusions}

1. Concentrations of many constituents, including calcium, magnesium, sulfate, manganese, zinc, and cadmium, are substantially greater in Level 2 water samples compared to Level 3 water samples, and these constituents approach or exceed concentrations observed in Level 1 portal effluent.

2. Water in Level 3 does not exit the portal but was observed to flow into open mine works (raises and ore chutes) and down to lower portions of the mine.

3. Redox determinations and measured dissolved oxygen in water samples collected in Levels 2 and 3 show that these waters are well oxygenated and are classified as oxic waters.

4. Oxygen and hydrogen isotopic compositions of water samples collected along Level 2 do not display a spatial trend of becoming lighter with distance into the hillside, suggesting that thickness of overburden is not the primary control of residence time for these waters. Some water collected along 
Level 2 likely moves through mine workings, altering naturalflow paths. This is consistent with the observation by Manning and others (2008a) that groundwater-residence time for water discharging from the Standard Mine is largely composed of water that is less than one year old. Time series oxygen and hydrogen isotopic compositions of water discharging from the Level 1 portal displayed a seasonal signature suggesting that groundwater-residence time is on the order of weeks to months.

5. The likely source of dissolved cadmium, zinc, copper, and lead is the oxidation of sulfides (sphalerite, chalcopyrite, and galena) from within the Standard Mine. These ore minerals occur within unmined portions of the mineralized-vein system, within plugged ore chutes, and as muck piles in the mine workings. The increase in dissolved constituents between Levels 3 and 2 likely is a result of increased water-rock interaction (oxygenated groundwater and sulfide minerals) between these two levels.

\section{References Cited}

Ball, J.W., and Nordstrom, D.K., 1991, User's manual for WATEQ4F, with revised thermodynamic data base and test cases for calculating speciation of major, trace, and redox elements in natural waters: U.S. Geological Survey OpenFile Report 91-183, 189 p.

Barringer, J.L., and Johnsson, P.A., 1989, Theoretical considerations and a simple method for measuring alkalinity and acidity in low-pH waters by gran titration: U.S. Geological Survey Water-Resources Investigations Report 89-4029, $35 \mathrm{p}$.

Briggs, P.H., 2002, The determination of twenty-seven elements in aqueous samples by inductively coupled plasmaatomic emission spectrometry, in Taggart, J.E., Jr., ed., Analytical methods for chemical analysis of geologic and other materials, U.S. Geological Survey: U.S. Geological Survey Open-File Report 02-223, chapt. F, 11 p.

Brinton, T.I., Antweiler, R.C., and Taylor, H.E., 1995, Method for the determination of dissolved chloride, nitrate and sulfate in natural water using ion chromatography: U.S. Geological Survey Open-File Report 95-426, 16 p.

Caine, J.S., Manning, A.H., Berger, B.R., Kremer, Y., Guzman, M.A., Eberl, D.D., and Schuller, K., in press, Characterization of geologic structures and host rock properties relevant to the hydrogeology of the Standard Mine in Elk Basin, Gunnison County Colorado: U.S. Geological Survey Open-File Report 2010-1008.

Colorado Division of Reclamation Mining and Safety, 2007, Draft underground assessment, Standard Mine Superfund site, Gunnison County, Colorado: Denver, Colorado, 37 p.
Epstein, Samuel, and Mayeda, T., 1953, Variation of ${ }^{18} \mathrm{O}$ content of waters from natural sources: Geochimica et Cosmochimica Acta, v. 4, p. 213-224.

Fleischer, Michael, 1955, Minor elements in some sulfide minerals, in Bateman, A.M., ed., Economic geology, fiftieth anniversary volume, 1905-1955, Pat II: Lancaster, Pa., Lancaster Press, p. 970-1024.

Graves, J.T., 2009, Underground investigation of Standard Mine Level 2, Gunnison County, Colorado: Colorado Division of Reclamation, Mining and Safety Report, 23 p.

Kendall, Carol, and Coplen, T.B., 1985, Multisample conversion of water to hydrogen by zinc for stable isotope determination: Analytical Chemistry, v. 57, p. 1437-1440.

Kuehner, E.C., Alvarez, R., Paulsen, P.J., and Murphy, T.J., 1972, Production and analysis of special high-purity acids purified by sub-boiling distillation: Analytical Chemistry, v. 44 , p. 2050-2056.

Lamothe, P.J., Meier, A.L., and Wilson, S.A., 2002, The determination of forty-four elements in aqueous samples by inductively coupled plasma-mass spectrometry, in Taggart, J.E., Jr., ed., Analytical methods for chemical analysis of geologic and other materials, U.S. Geological Survey: U.S. Geological Survey Open-File Report 02-223, chapter H, $13 \mathrm{p}$.

Manning, A.H., Verplanck, P.L., Mast, M.A., and Wanty, R.B., 2008a, Hydrogeochemical investigation of the Standard Mine vicinity, upper Elk Creek Basin, Colorado: U.S. Geological Survey Scientific Investigations Report 2007-5265, $131 \mathrm{p}$.

Manning, A.H., Verplanck, P.L., Mast, M.A., and Wanty, R.B., 2008 b, Presentation showing results of a hydrogeochemical investigation of the Standard Mine vicinity, upper Elk Creek basin, Colorado: U.S. Geological Survey Open-File Report 2008-1012, 19 p.

Meier, A.L., Grimes, D.J., and Ficklin, W.H., 1994, Inductively coupled plasma-mass spectrometry-A powerful analytical tool for mineral resource and environmental studies [abs], in Carter, L.M.H., Toth, M.I., and Day, W.C., eds., U.S. Geological Survey Research on Mineral Resources - 1994, Part A-Program and abstracts, ninth V.E. McKelvey Forum on mineral and energy resources: U.S. Geological Survey Circular 1103-A, p. 67-68.

Minsley, B.J., Ball, L.B., Burton, B.L., Caine, J.S., CurryElrod, E., and Manning, A.H., in press, Geophysical characterization of subsurface properties relevant to the hydrology of the Standard Mine in Elk Basin, Colorado: U.S. Geological Survey Open-File Report 2009-1284.

Stookey, L. L., 1970, FerroZine - a new spectrophotometric reagent for iron: Analytical Chemistry, v. 42, p. 779-781. 
Sharp, J.E., 1978, A molybdenum mineralized breccia pipe complex, Redwell Basin, Colorado: Economic Geology, v. 73 , p. $369-382$.

To, T.B., Nordstrom, D.K., Cunningham, K.M., Ball, J.W., and McCleskey, R.B., 1999, New method for direct determination of dissolved $\mathrm{Fe}(\mathrm{III})$ concentrations in acid mine waters: Environmental Science and Technology, v. 33, p. 807-813.

Verplanck, P.L., Manning, A.H., Mast, M. A., Wanty, R.B., McCleskey, R.B., Todorov, Todor, and Adams, Monique, 2007, Selected water-quality data for the Standard Mine, Gunnison County, Colorado, 2006-2007: U.S. Geological Survey Open-File Report 2007-1241, 12 p.

Wood, R.H., II, and Oerter, E.J., 2007, History, geology, and environmental setting of the Micawber mine and elk load in the Ruby Mining District, Gunnison National Forest, Gunnison County, Colorado: Colorado Geological Survey Open-File Report 08-10, 85 p.
Publishing support provided by:

Denver Publishing Service Center

For more information concerning this publication, contact: Team Chief Scientist, USGS Central Mineral Resources Box 25046, Mail Stop 973

Denver, CO 80225

(303) 236-1562

Or visit the Central Mineral Resources Team Web site at: http://minerals.cr.usgs.gov/ 
